\title{
Review
}

\section{Guiding Differentiation of Stem Cells In Vivo by Tetracycline-Controlled Expression of Key Transcription Factors}

\author{
Elena N. Kozlova* and Christian Berens $\dagger$ \\ *Department of Neuroscience, Uppsala University, Uppsala, Sweden \\ $†$ Division of Microbiology, Department of Biology, Friedrich-Alexander-University \\ Erlangen-Nuremberg, Erlangen, Germany
}

\begin{abstract}
Transplantation of stem or progenitor cells is an attractive strategy for cell replacement therapy. However, poor long-term survival and insufficiently reproducible differentiation to functionally appropriate cells in vivo still present major obstacles for translation of this methodology to clinical applications. Numerous experimental studies have revealed that the expression of just a few transcription factors can be sufficient to drive stem cell differentiation toward a specific cell type, to transdifferentiate cells from one fate to another, or to dedifferentiate mature cells to pluripotent stem/progenitor cells (iPSCs). We thus propose here to apply the strategy of expressing the relevant key transcription factors to guide the differentiation of transplanted cells to the desired cell fate in vivo. To achieve this requires tools allowing us to control the expression of these genes in the transplant. Here, we describe drug-inducible systems that allow us to sequentially and timely activate gene expression from the outside, with a particular emphasis on the Tet system, which has been widely and successfully used in stem cells. These regulatory systems offer a tool for strictly limiting gene expression to the respective optimal stage after transplantation. This approach will direct the differentiation of the immature stem/progenitor cells in vivo to the desired cell type.
\end{abstract}

Key words: Cell survival; Central nervous system; Gene regulation; Transcription factor; Directed differentiation

\section{PROMISES AND OBSTACLES FOR STEM CELLS IN CELL REPLACEMENT THERAPY}

Transplantation of stem or progenitor cells is an attractive and, therefore, frequently proposed therapeutic option to replace cells lost or injured in traumatic and degenerative disorders in which the intrinsic capacity for cell renewal is limited or absent. Consequently, several phase I clinical trials have already been started or have just received approval to transplant stem cells with cell replacement as one of the objectives. A variety of stem cell sources have been used to generate cardiomyogenic cells for transplantation to patients who have suffered myocardial infarction (85), but see also (198). Muscle satellite cells or myoblasts were transplanted to patients with muscular dystrophy (179). Damaged cornea was restored by transplanting autologous stem cells derived from corneal limbal epithelium (137). Autologous human neural stem cells (NSCs) were used to replace dopaminergic (DA) neurons in Parkinson's disease (PD) (109). Clinical trials with neural stem cells are underway for chronic spinal cord injury (http://www. stemcellsinc.com/Therapeutic-Programs/Clinical-Trials. htm), amyotrophic lateral sclerosis (ALS) (115), and stroke (116). Approval has recently been granted for clinical trials with transplantation of human embryonic stem cells (hESCs) to replace photoreceptors in juvenile and age-related macular degeneration (http://www. advancedcell.com/patients/clinical-trial-information/), oligodendrocytes in spinal cord injury (116), and motor neurons in spinal muscular atrophy (SMA) (115).

Although numerous experimental studies have provided evidence that stem cell transplants can contribute to tissue repair and functional recovery in a range of animal models for injury or disease, it is still not mechanistically clear how the transplanted cells mediated these beneficial

Received July 15, 2011; final acceptance November 15, 2011. Online prepub date: March 28, 2012.

Address correspondence to Elena N. Kozlova, Department of Neuroscience, Uppsala University, Box 593 , 75124 Uppsala, Sweden.

Tel: +46-18-471-4111; Fax: +46-18-51-15-40; E-mail: elena.kozlova@ neuro.uu.se or Christian Berens, Division of Microbiology,

Department of Biology, Friedrich-Alexander-University Erlangen-Nuremberg, Staudtstr. 5, D-91058 Erlangen, Germany. Tel: +49-9131-85-28084;

Fax: +49-9131-85-28082; E-mail: berens.chris@gmail.com 
effects. In many instances, symptom amelioration appears to be mediated by cell-protective and anti-inflammatory mechanisms or by trophic bystander effects rather than through replacement of the cells lost $(23,123,212)$.

However, many disorders including PD, Huntington's disease, ALS, multiple sclerosis, stroke and traumatic injuries to the central nervous system (CNS), heart disease, or the loss of $\beta$-cells in patients with type 1 and type 2 diabetes require that the cells permanently damaged or lost are replaced. Clinical trials with stem cell transplants in, for example, cardiac disease, have shown that this approach can be safe and may even have beneficial effects, but also that the long-term survival of the transplanted cells is typically poor (85). This problem is frequently observed with stem cell transplantations aimed at replacing lost cells (21); other commonly occurring problems are incomplete differentiation of the transplanted cells (70) or their differentiation to other types of cells rather than exclusively to the desired ones $(57,100,125)$.

At the same time, differentiation of ESCs toward many different cell types has been achieved in vitro $(20,156)$, thereby providing cell sources for regenerative medicine. There are many examples when in vitro predifferentiated ESCs were successfully transplanted into the host and became functional specific cell types $(90,178,208)$. Often however, these transplanted cells display unusually high and accelerated cell mortality after transplantation and, as a consequence, have inadequate therapeutic efficacy as well as the risk of inducing undesirable inflammatory reactions in the host tissue $(9,160,164)$. This affects neural cells in particular, which have a very narrow time window for successful transplantation to a host $(43,186)$. It has been demonstrated that neural cells have to be transplanted at an early postmitotic stage to avoid damage to their fibers during the transplantation procedure. Once the cells have been transplanted, their survival and further differentiation, including incorporation to the local neuronal circuitry, becomes entirely dependent on their interaction with the host environment. It would, therefore, be of advantage if the properties of the transplanted stem cells could be influenced not only before but also after their transplantation.

In vitro stem cell differentiation is either controlled by adding specific small molecules to the culture medium $(110,111,187,208,227)$ by ectopically expressing proteins that are essential to drive the differentiation process to the desired cell type either by transfecting expression vectors for their genes $(62,107,120)$ or by introducing the recombinant proteins $(93,220)$ or their encoding mRNAs themselves (162).

Clearly, this small molecule-driven approach will not allow clean, clear-cut control over stem or progenitor cell fate after transplantation due to systemic interference with the other cell types in the host organism. We therefore propose an alternative approach in which we artificially control stem cell destiny from outside via heterologous expression of a limited set of genes essential for the differentiation process. Inducible gene regulation systems, exemplified by, but not limited to, the Tet system are triggered externally by administering small molecules to the recipient organism. They can, thus, provide the tools we need to help control and guide the in vivo differentiation of stem cells after their transplantation. These systems make it possible to insert cell autonomous survival or differentiation protocols into stem/progenitor cells prior to their transplantation, which can then be activated after transplantation in the cells we want for the period of time we need.

\section{EXPRESSION OF KEY TRANSCRIPTION FACTORS TO GUIDE CELL DIFFERENTIATION}

An important aspect in any cell replacement therapy is to generate the required cell type exclusively and efficiently in an environment that is either indifferent to or even unfavorable for stem/progenitor cell differentiation to mature cell types $(26,42,78,204)$. Since transcription factors (TFs) are downstream effectors of signaling pathways, their ectopic expression can be used instead of external cues to set up a cell autonomous program, which will then direct cell differentiation to the desired cell type. The crucial step involved in this approach will be to isolate the respective minimal set of transcription factors required to flip the switch toward the desired cell type out of the entire set of transcription factors present during developmental cell patterning and specification. One way to identify the relevant TFs for a certain differentiation pathway is to follow the normal steps taken during natural development (76). A second, alternative method, which is increasingly being applied, is to identify the key transcription factors for a specific differentiation step by transfecting or transducing the host cells with a mixture of constructs expressing different transcription factors that are suspected to be important for the differentiation process. An initially successful "TF differentiation cocktail" can then be deconvoluted to identify the minimal TF set necessary to guide the differentiation process. There are elegant examples demonstrating that a limited number of TFs is sufficient to completely change the differentiation state of the cells - the original generation of iPSCs (193) and the recent transdifferentiation of mature fibroblasts to functional neurons (201).

That transcription factors have the power to control cell fate has been demonstrated convincingly in many studies involving not just cellular reprogramming and dedifferentiation but also transdifferentiation or directed differentiation [for a minireview, see (27)]. Figure 1 shows how these three processes are connected with each other. In the original landmark reprogramming protocol, four transcription factors of 24 selected genes were sufficient to induce mature murine fibroblasts to readopt a pluripotent state (193). Careful selection of the starting cell type could even further reduce this requirement to just a single factor, 


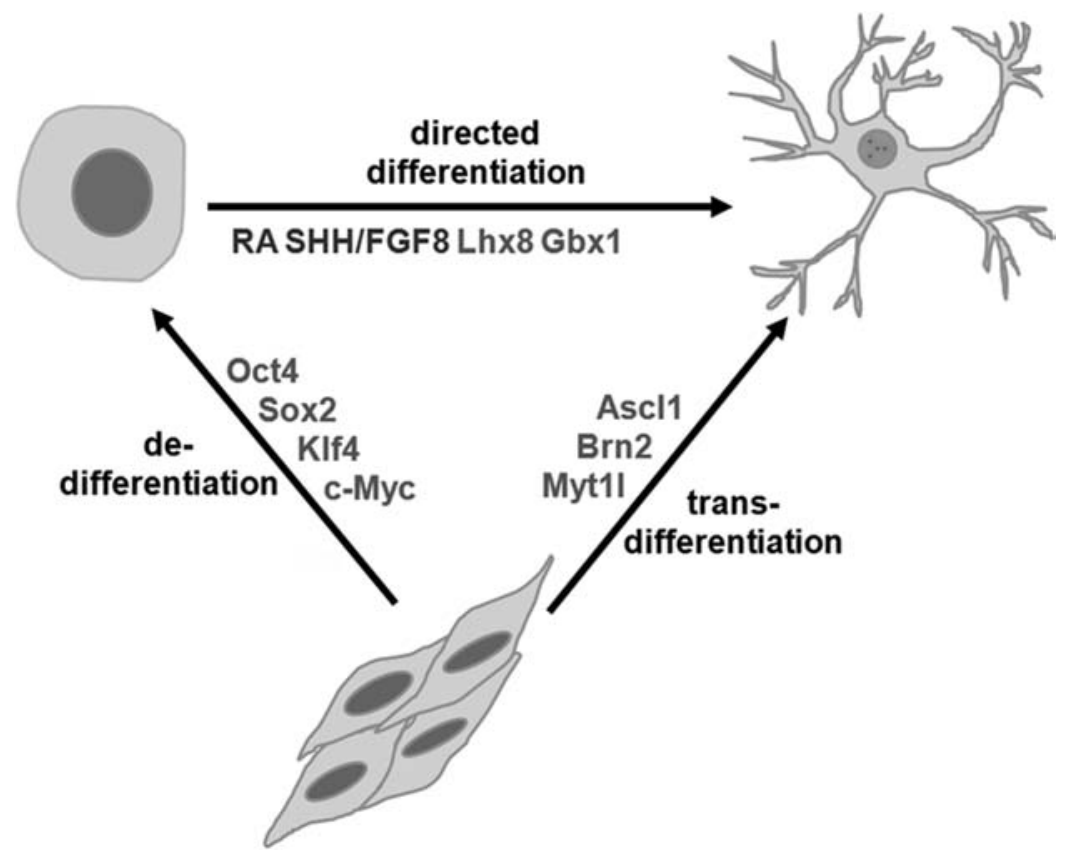

Figure 1. Transitions between cell types. An embryonic stem cell (top left), a neuron (top right), and fibroblasts (bottom) are arranged as a triangle. The differentiation steps that lead to their interconversion are indicated, as well as the relevant transcription factors, growth factors, and morphogens (RA, retinoic acid; SHH, sonic hedgehog; FGF8, fibroblast growth factor 8) that were used [the dedifferentiation factors are from (193), the transdifferentiation factors from (201), and those for directed differentiation were taken from (18)].

octamer binding transcription factor 4 (Oct4) $(95,96)$. Transdifferentiation is an equally impressive example of the important role transcription factors play in deciding cell fate. Transdifferentiation describes the direct conversion of one cell type to another through simultaneous down-regulation of one genetic program and concomitant up-regulation of the new genetic program (86). For example, B-cells are converted to macrophages by ectopically expressing the transcription factors CCAAT-enhancerbinding proteins $\alpha(\mathrm{CeBP} \alpha)$ and $\mathrm{CeBP} \beta$ (215). In adult mice, mature pancreatic exocrine cells transdifferentiate into cells closely resembling $\beta$-cells after infection with adenoviruses expressing the three transcription factors neurogenin 3 (Ngn3), pancreatic and duodenal homeobox 1 (Pdx1), and musculoaponeurotic fibrosarcoma oncogene homolog A (Mafa). These three were identified out of an initial group of nine genes, which exhibited $\beta$-cell developmental phenotypes when mutated (224). Starting from a pool of 19 candidate genes, a combination of three transcription factors, achaete-scute complex homolog 1 (Ascl1 or Mash1), brain-2 (Brn2 or OCT7), and myelin transcription factor 1-like (Myt11), was found to transform both murine and human fibroblasts directly into functional neurons $(151,201)$. Human fibroblasts were then further differentiated toward dopaminergic neurons by additional expression of the two genes LIM homeobox transcription factor $1 \alpha($ Lmxla) and forkhead box A2 (FoxA2) (151). Other examples include transforming fibroblasts into cardiomyocytes (80) and cells from a human dermal subset into blood cell progenitors (189). In directed differentiation, specific cell types are generated from stem/progenitor cells by treating them either with combinations of trophic factors and/or small molecules $(14,30,77,79)$, by ectopically expressing transcription factors, or by a combination of both $(19,51,58,138)$. Panman et al. (143) induced specific neuronal subtypes effectively with single transcription factors if the neural progenitor cells were competent to differentiate to the desired cell type. But if the stem/progenitor cells had a nonpermissive regional character, then a combination of "regionalizing" regulatory factors together with the subtype-specific factor were needed to achieve efficient differentiation.

\section{CURRENT STATE OF STEM CELL TRANSPLANTATION AS CELL REPLACEMENT THERAPY FOR MAJOR DISORDERS}

There is a long list of medical conditions that are potential therapeutic targets for stem cell transplantation. Here, we limit our discussion to several disorders with huge impact on the affected individuals and on society. Based on developmental studies and in vitro differentiation protocols, we show the set of key TFs, which play an 
important role in generating the respective corresponding types of cells. These TFs may be activated for advanced differentiation of transplanted predifferentiated ESCs in vivo after transplantation in order to guide their further differentiation toward functional cells.

\section{Parkinson's Disease}

In PD, the dopamine-releasing neurons in the substantia nigra are gradually lost, resulting in the progressive and severely disabling motor dysfunction, which is the hallmark of this disease. Previous studies in experimental animal models of PD have shown that dopamine release can be restored and motor dysfunction reversed by transplantation of embryonic neurons into the striatum [reviewed in (114)]. Clinical trials with human embryonic DA neurons initially provided encouraging results, but later follow-up evaluations failed to demonstrate any significant improvement [reviewed in (114)].

DA neurons have been generated in vitro from iPSCs, ESCs (93), mesenchymal stem cells (MSCs), regional stem/progenitor cells, and fibroblasts. In vitro predifferentiated cells were subsequently grafted into the striatum and found to partially reverse PD-like symptoms in animal models $(30,145,161,169)$. However, the mechanism(s) responsible for symptom reversal are not fully understood, since functional improvement in the 6-hydroxy dopamine rat model of PD was shown to occur from human neural progenitor cell transplants without differentiation to DA neurons (75). More recently, using the same animal model, forced expression of the TF Lmx1a in striatal mouse ESC transplants resulted in robust graft survival and extensive striatal dopaminergic innervation by the grafted cells (51).

Several transcription factors and extrinsic factors were identified to be crucial for dopaminergic neural differentiation. Stem cells harvested from the E12.5-13.5 mouse ventral midbrain express Neurogenin $2(91,195)$, thereafter nuclear receptor related 1 (Nurr1) (4) and subsequently Mash1 (146). The nuclear transcription factor Nurr1 is involved in the development and maintenance of the midbrain dopaminergic neuronal phenotype (82). There is a well-established correlation between olfactory symptoms and PD (16). This provides a possible link between PD and adult neural stem cells, which are continuously produced in the subventricular zone (SVZ) of the lateral ventricle and migrate to the olfactory bulb where they give rise to interneurons. Glial cell line-derived neurotrophic factor (GDNF) has been shown to protect and restore DA neurons in injury models and is being evaluated for the treatment of Parkinson's disease (214).

Generation of functional DA neurons was also achieved from hESCs in vitro (30), in vivo from neural progenitors expressing orthodenticle homeobox 1 (Otx1) (64) and after reprogramming mouse and human somatic cells by viral transduction of four transcription factors, Oct4, Krüppel-like factor 4 (Klf4), sex-determining region Y box 2 (Sox2), and myelocytomatosis viral oncogene homolog (c-Myc) $(119,147,191)$. Recently, human iPSCs were efficiently generated from skin biopsies of PD patients by using doxycycline (DOX)-inducible delivery of reprogramming factors (182). These reprogrammed fibroblasts were made by cotransducing lentiviral vectors expressing a Tet-On transactivator (FUW-rtTA2 ${ }^{\mathrm{S}}$-M2) together with DOX-inducible transgene cassettes expressing either the four or just three (Oct4, Sox2, Klf4) reprogramming factors. For the subsequent directed differentiation of hESCs into DA neurons, conventional in vitro protocols were used $(21,45,94,149,169)$. DA neurons were also recently generated from human mature fibroblasts by enforced expression of Lmx1a and FoxA2 in addition to the three neural transdifferentiating factors Asc11, Brn2, and Myt11 (151).

Nurr1 alone is not sufficient to drive mesencephalic stem/progenitor cells to the dopaminergic phenotype (81), but differentiation to dopaminergic neurons was achieved in collaboration with paired-like homeodomain 3 (Pitx3) (180). Recently, new insights on the role of Nurr1 in PD revealed that Nurr1 appears to protect against loss of dopaminergic neurons in part by limiting the production of neurotoxic mediators by microglia and astrocytes (167). This observation highlights the importance of controlling the environmental cues to achieve optimal survival of transplanted DA neurons.

\section{Stroke and Traumatic Brain Injury}

Stroke is the third most common cause of death in the Western world and one of the main causes of long-term severe disability. One major line of research attempts to promote recovery by recruiting endogenous neural stem cells to the ischemic territory, whereas the other focuses on stem cell transplants. The brain tissues affected by stroke or trauma undergo a complex series of pathological events with spatially and temporally different requirements on stem cell transplants. Initially, neuroprotection should have the highest priority, followed by tissue repair, and finally the restoration of as much as possible of the damaged neural circuitry. The main components of neuronal networks in the brain are glutamatergic and $\gamma$-aminobutyric acid-ergic (GABAergic) neurons as well as astrocytes. These cell types have been generated in vitro primarily from ESCs or from region-specific neural precursors from embryos or adult mice and rats $(65,221)$. Stem/progenitor cells delivered intravascularly (177) or intracerebrally (5) to the ischemic brain are able to improve symptoms, even if the generation of functional neurons does not occur.

Thus, the positive results of stem cell transplants in experimental stroke models so far are most likely the 
consequence of the release of trophic factors, stimulation of intrinsic repair processes, or a combination of both.

Recent publications proposed stem cells not only as a potential source for cell replacement in central nervous system injury but also as a source for trophic molecules that might minimize damage and promote recovery $(24,113)$. NSCs appear to be an effective source for successful differentiation into representative cell types in parts of the brain most commonly affected by stroke, such as cortical projection neurons (46), interneurons (172), hippocampal pyramidal neurons $(36,46)$, motor neurons (54), astrocytes $(47,68,210)$, and oligodendrocytes (154,217). Human- and mouse-derived ESCs, including the more recently described iPSCs, are also able to differentiate into all adult cell types, including functional neurons $(13,135)$ and glia $(22,44,171)$.

Neurons and astrocytes are derived from common multipotent neural progenitor cells, which sequentially pass through phases of expansion, neurogenesis, and astrogenesis $(71,131)$. If the transcription factor sequence glioma-associated oncogene family zinc finger 2 (Gli2)Sox2-hairy and enhancer of split 5 (Hes5) maintains the undifferentiated state of neural precursor cells (194), the transcription factor paired box 6 (Pax6) controls neurogenesis and also regulates proliferation, differentiation, and migration of astrocytes in the CNS (168). The suppression of proneural basic helix-loop-helix (bHLH) genes, primarily Ngn1 and Ngn2, results in stem cell differentiation toward the glial lineage (72). Differentiation of GABAergic cortical neuron differentiation is driven by the transcription factors Nkx2.1, Mash1, and distalless homeobox 1 (Dlx1) $(34,155)$ [see also (132) for a review]; glutamatergic cortical neuron development by the sequence Pax6-T-box, brain 2 (Tbr2) neuronal differentiation 1 (NeuroD), and Tbr1 $(61,69)$, that of cortical oligodendrocytes by a succession of Sox10, oligodendrocyte transcription factor $1 / 2$ (Olig1/2), Mash 1, and Nkx2.2 (148,225), whereas cortical astrocytes were either associated with a Sox9, inhibitor of DNA binding 1/3 (Id1/3), Hes1/5 expression pattern $(87,163)$, or with the combination of Sox10, Nkx2.2, Olig2, and Olig1 (25).

\section{Myocardial Disease}

Ischemic heart disease is the most common cause of death in the Western world. Cardiomyocytes are the contracting elements of the heart, and the intrinsic capacity of the heart to replace these cells is very limited. Transplantation of stem cells that can replace lost cardiomyocytes is therefore an attractive option to treat this condition. Cardiomyocytes have been generated in vitro from a wide range of stem/progenitor cells, including iPSCs $(53,104,150)$, ESCs $(15,184)$, hematopoietic progenitor/stem cells, MSCs $(6,31,56,63)$, and cardiomyocyte progenitor cells (181). An additional source for repair of myocardial contractility are skeletal myoblasts (140), although they do not seem to be able to differentiate to cardiomyocytes $(108,159)$. Intravascular delivery or cardiac transplants of multipotent or predifferentiated cardiogenic cells from these stem cell sources have been shown to promote cardiac structural repair and functional restoration in animal models of myocardial injury $(52,66,84,126,141)$. The encouraging results from this experimental research have prompted several clinical trials in patients with myocardial disease, using different types of progenitor/stem cells $(85,152)$. The results from these studies are inconsistent, but some report beneficial effects on cardiac function in the recipient patients. Differentiation of the transplanted cells to cardiomyocytes appears to be absent or minimal, their long-term survival is poor, and most importantly, the functional improvement observed does not appear to depend on their presence $(103,188)$.

Multipotent cardiac progenitor cells (CPCs), expressing $\mathrm{Nkx} 2.5$, fetal liver kinase 1 (Flk1), or insulin gene enhancer protein (Is11), can be isolated from early embryos or generated from ESCs and give rise to cardiomyocytes as well as endothelial and smooth muscle cell lineages $(32,89,105,133,213)$.

The discovery that heart defects in humans often result from haploinsufficiency of cardiac-specific TFs suggests that strategies to activate such developmental regulators may contribute to the differentiation of stem cells that are transplanted with the purpose of producing substituting functional heart cells. Thus, mutations in Nkx2.5 (174), T-box 5 (Tbx5) (11), Tbx1 (129,203), or GATA4 (55), which activate the genes in the core cardiac network [reviewed in (142)], result in serious heart abnormalities. In addition, recent studies have revealed that these myogenic TFs activate the expression of a set of conserved microRNAs (miRNAs) that regulate transcriptional networks, resulting in precise cellular responses to developmental, physiological, and pathological signals [reviewed in $(153,209)]$. Activation of neuregulin-1 (NRG-1) in ESCs resulted in up-regulation of the expression of the cardiac-restricted TFs Nkx2.5 and GATA-4 (205).

\section{Insulin-Producing $\beta$-Cells}

Type 1 diabetes is characterized by an autoimmunemediated loss of insulin-producing $\beta$-cells in the pancreatic islets of Langerhans. Today, transplantation of either the entire pancreas or of isolated islets has become a treatment of choice for selected patients with diabetes mellitus $(50,165)$. However, long-term results after islet transplantation are disappointing with adequate graft function seen in less than $10 \%$ of the patients after 5 years (166). Furthermore, the number of patients in need of new $\beta$-cells far outnumbers the limited access to islet tissue for transplantation. Transplantation of stem cells to replace the lost $\beta$-cells is therefore an attractive therapy for long-term 
treatment of type 1 diabetes and also for some cases of type 2 diabetes. Insulin-producing $\beta$-cells have been generated from several sources, including ESCs $(8,49,121,175,200)$, stem/progenitor cells from the exocrine pancreas $(41,62,124,139)$, biliary ducts (136), MSCs from various sources $(88,144,216)$, and iPSCs derived from fibroblasts of patients with diabetes type 1 (117). Human ESCs have been converted to $\beta$-cells capable of synthesizing insulin through a stepwise procedure of transcriptional regulation that mimics the normal development of $\beta$-cells $(37,38)$. Exocrine pancreatic cells were also shown to give rise to insulin-producing $\beta$-cells by transcriptional reprogramming with a specific combination of the three transcription factors Ngn3, Pdx1, and Mafa (224).

Numerous studies have reported beneficial effects of MSC transplants in animal models of type 1 diabetes. They are presumably due to modification of inflammatory processes and to improved vascularization $[(88,144)$, reviewed in (202)]. Transplantation of ESCs to diabetic mice also improved glucose homeostasis indirectly by promoting endogenous $\beta$-cell neogenesis (98). Human ESCs predifferentiated to committed pancreatic endoderm developed into functional $\beta$-cells after transplantation to immunecompromised mice (101). Interestingly, treatment of the recipients with the $\beta$-cell toxin streptozotocin destroyed their endogenous $\beta$-cell population, but the grafted cells were protected and provided a functional source of insulin. Thus, although efficient and reproducible replacement of lost $\beta$-cells in type 1 diabetes has still not been fully achieved with stem cell transplants [reviewed in (197)], promising steps in this direction have been taken.

Precursor cells that give rise to the definitive endocrine pancreas emerge at E13.5 and express a series of key TFs, including Pdx 1 and hepatocyte nuclear factor 6 (Hnf6), followed by Ngn-3, $\beta 2 /$ NeuroD, and Pax4 (1).

Differentiation of $\beta$-cells/progenitors from human ESCs was achieved in vitro by activating either Pax4 (112) or Pdx1 expression $(29,106)$ from mouse ESCs and from progenitor cells by activation of Ngn3 expression $(176,218)$ and in liver progenitor cells by activation of Pdx1 (83). In already differentiated cells, ectopic expression of Pax4 lead to redifferentiation of endocrine precursor cells (35), whereas in liver cells activation of Pdx1 and Ngn3 was required (219). Adult pancreatic exocrine cells were reprogrammed with Ngn3, Pdx1, and Mafa (224).

\section{DRUG-INDUCIBLE REGULATION OF TRANSCRIPTION FACTOR EXPRESSION IN CELL DIFFERENTIATION}

\section{General Remarks}

In the previous two sections, we provided several examples, out of many possible, that enforced expression of only a few key transcription factors, which are normally present during development, can induce cell differentiation to a desired cell type. Major efforts in current stem cell research focus on in vitro methods to induce commitment to a defined cell type in the donor cells prior to their transplantation. This valuable approach resulted in the successfully continued differentiation of neural stem cells transplanted to a developing nervous system (208). However, to guide differentiation of the transplanted cells to the right cell (sub)type out of the large number of different cell types they can diversify to and to have them establish the correct connections after grafting are still major challenges for successful neural stem cell transplantation. To meet these challenges, inducible gene regulation offers a tool to control differentiation of stem/ progenitor cells after their transplantation to the damaged or diseased tissue.

\section{Inducible Gene Regulation Systems}

Inducible gene regulation systems have several properties that predestine them for in vivo control of gene expression: (i) they allow transgene expression to be turned on or off at any desired time-point (60), (ii) they also allow transgene expression to be turned on or off repeatedly (128), and (iii) the transgene expression level can be modulated by titrating the effector molecule's concentration (170). This allows flexible adjustment of transgene expression to the specific needs of the differentiation protocol previously established in vitro [reviewed in (33)]. The importance of conditional regulation systems for inducing cell fate changes becomes clear from studying the large amount of published data on the generation of iPSCs from partially or fully differentiated cell types, which has clearly shown that (i) some cell types require longer expression of the reprogramming factors than others (118); (ii) expression of the reprogramming factors is needed only transiently, as evidenced from the down-regulation of their expression as a hallmark of true iPSCs (28) or the successful generation of iPSCs using either adenoviral vectors (183) or recombinant transducing proteins $(92,223)$; (iii) the expression levels of the four reprogramming factors required for dedifferentiation vary from cell type to cell type (207); and (iv) careful selection of the cell type used to initiate reprogramming can reduce the number of transcription factors needed down to a single one, Oct-4 (96). Taken together, the properties of inducible regulation systems nicely fulfill the requirements needed for controlling cell fate.

In most cases, the TFs needed to guide cell differentiation are expressed only for brief periods of time (151). It is therefore advisable to use conditional expression systems that require the presence of external ligands to induce target gene expression. Such regulatory systems are typically termed "ON" and two different implementations will be presented in the next section. The use of "OFF"-type regulatory systems, in which the presence of an effector 
molecule turns transgene expression off, would require this effector molecule to be applied for the remainder of the organism's life to prevent complications-which is clearly not acceptable in a clinical setting.

\section{The Tet System}

The Tet system is the most widely used conditional system for inducible control of transgenes in cell lines and organisms [reviewed in $(17,59)$ ]. Its use in vivo and in gene therapy applications has been extensively reviewed recently $(185,196,206)$, so that we are only going to focus on several, in our opinion, key aspects of Tet regulation with respect to cell differentiation in vivo. Tet system regulation is derived from bacterial tetracycline resistance determinants (17) and functions as an artificial transcription unit (Fig. 2). One component is a chimeric transcription factor, generated by fusion of a eukaryotic regulatory domain to the bacterial tetracycline repressor TetR. The TetR portion mediates sequence-specific DNA-binding and effector response, the regulatory domain transcriptional readout. The second component is a hybrid promoter formed by positioning multiple repeats of the specific TetR binding site tet $O$ upstream of a TATAbox containing minimal promoter (59).

Tet-On type regulatory setups, in which transgene expression is initiated by addition of an effector, can be realized by different strategies. One is to fuse a silencing domain to unmodified TetR (Fig. 2A). The resulting transregulators are termed tetracycline-dependent transsilencers (tTS). In most applications, the silencing

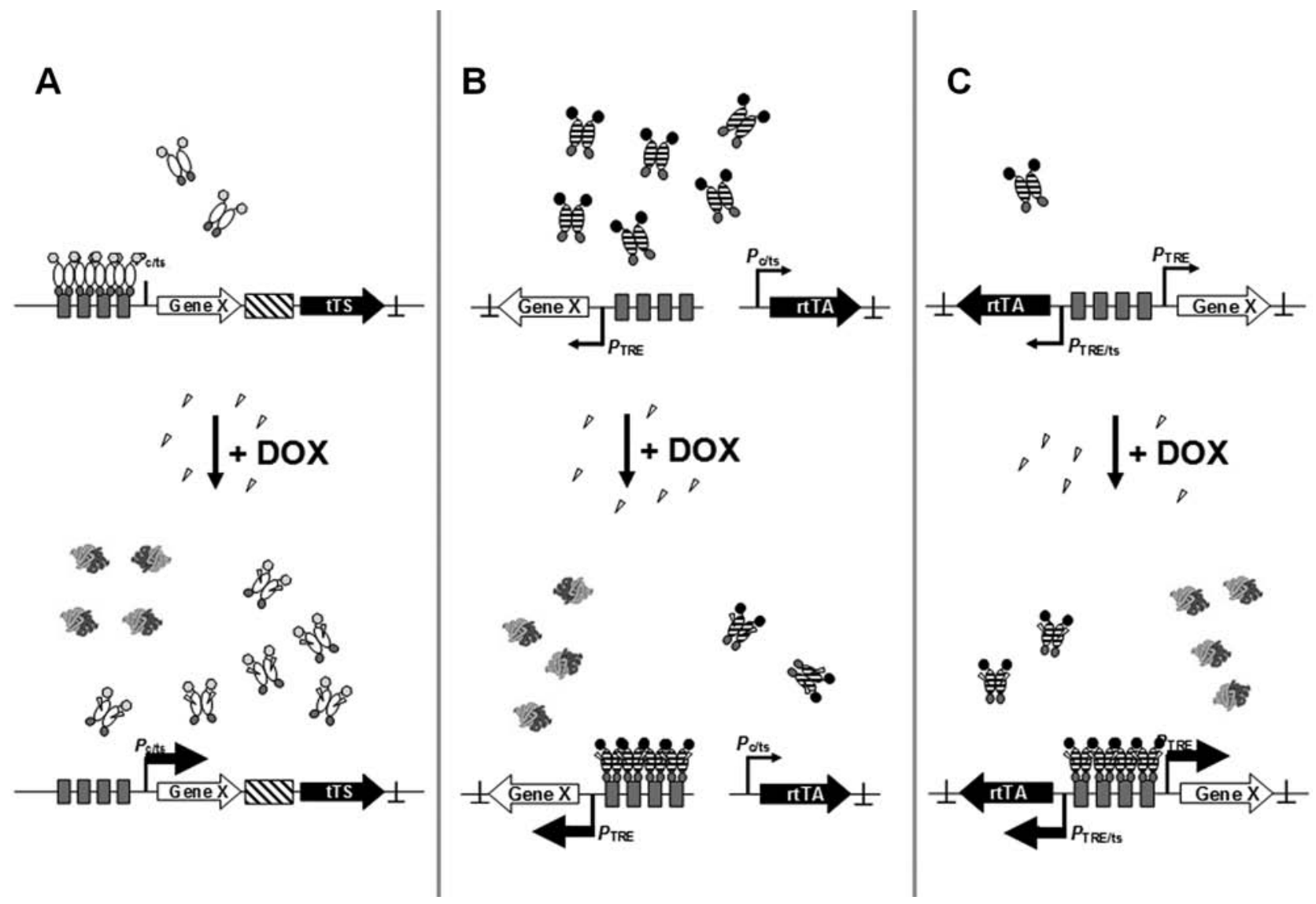

Figure 2. Regulatory principles of different Tet-On systems. (A) Repression by tetracycline-dependent transsilencer (tTS): In the absence of effector, tTS down-regulates expression by the promoter. In the presence of doxycycline (DOX), tTS dissociates from the promoter and both genes are expressed. (B) Regulation by a constitutively expressed reverse tetracycline-dependent transactivator (rtTA): rtTA is expressed independent of the presence of effector. In the presence of DOX, it binds to the promoter activating expression of the target gene. (C) Regulation by an autoregulatory rtTA loop: In the absence of effector, only small amounts of rtTA are made. After addition of DOX, rtTA binds to the promoter and activates expression of its own gene and of the transgene. The Tet-transregulators are symbolized by gray circles as DNA-binding domains, hatched ellipses representing rtTA and open ellipses TetR. A black circle symbolizes an activation domain, while a gray stop sign represents a repression domain. The transregulator-encoding genes are depicted as black arrows with inverse print, the target genes by an open arrow. Promoters are displayed as broken arrows with "TRE" representing a Tet-responsive element, "c" a constitutive, and "ts" a tissue-specific promoter. tTS- and rtTA-binding sites (tetO) are shown as gray boxes, an internal ribosome entry sequence as a hatched box, and polyA sites as $\perp$. DOX is depicted as open triangles. 
domain fused to TetR is the Krüppel-associated box (KRAB) domain from the human zinc finger transcription factor Kox1. It represses transcription from constitutive or cell-type-specific promoters effectively, but its presence can lead to irreversible silencing of target gene expression by introducing heterochromatin formation $(7,190,211)$. A typical expression vector for tTSmediated regulation is shown in Figure 3A. Its advantages are its small size that allows it to be introduced into lentiviral or adeno-associated virus (AAV) vectors. Its disadvantage is that any irreversible transgene silencing mediated by the KRAB domain should not already occur during the transduction and selection phase, prior to cell transplantation. Here, transgene expression has to be shut off to prevent premature differentiation of the stem cells. An effective alternative repression domain based on a "Pro-Leu-Asp-Leu-Ser" C-terminal binding protein (CtBP)-recruiting domain with reduced tendency to introduce irreversible transgene silencing was recently introduced $(39,67)$.

The second approach is based on using TetR mutants that absolutely require tetracyclines, like doxycycline, to bind to their operators (Fig. 2B, C). Once fused to activation domains, they are designated as reverse tetracycline-dependent transactivators (rtTA). Second(199) and third-generation rtTA variants (226) have been generated by random mutagenesis and screening in yeast or by viral evolution. They display no intrinsic leakiness and high sensitivity toward their effector, DOX. This is of great advantage, because the increased effector sensitivity should permit their usage in applications regulating gene expression in the central nervous system. This has been difficult with Tet-On systems in the past, due to their low sensitivity toward DOX (130). rtTA can either be expressed from constitutive or tissue-specific promoters (Fig. 3B) or in an autoregulatory setup (Fig. 3C).

With active polymerase II (Pol II) promoters, the transgene-expressing unit in a one-vector system should be insulated $(3,157)$. We routinely use $250 \mathrm{bp}$ core sequences derived from the chicken HS4 insulator (158), but other insulators are also available like the sns5 (40) and arylsufatase elements (134) from sea urchins. They were shown to be functional in erythroid cells (40) and in a mouse quadriceps muscle transduction model (134). Insulators shield the transgene expressing unit from position effects due to activating or silencing elements at the vector integration site and from the nearby promoter driving rtTA expression. This efficiently reduces the integration site-dependent leakiness that is often observed with inducible system. They also increase the yield of regulating clones and improve the homogeneity of transgene expression between different clones $(3,157)$. The size of the expression cassette
A

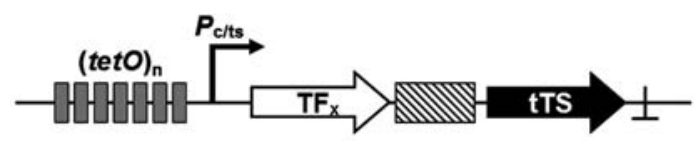

B

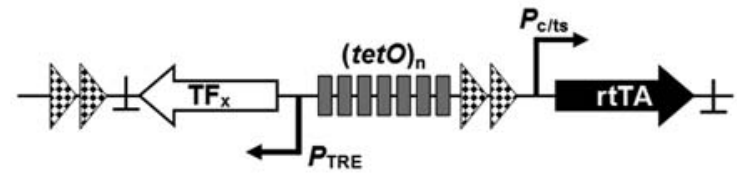

C

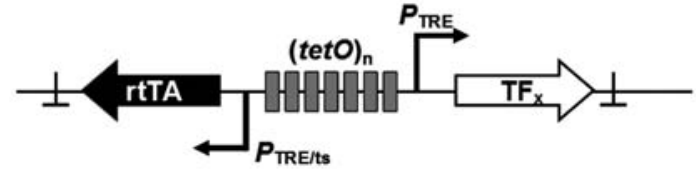

Figure 3. Typical designs for one vector Tet-On type regulatory systems (A) based on tTS-mediated regulation, (B) based on rtTA-mediated regulation, and (C) based on autoregulatory rtTA-mediated regulation. The Tet-transregulators are symbolized by a black arrow with inverse print, target genes by an arrow. Promoters are displayed as broken arrows with "TRE" representing a Tet-responsive element, "c" a constitutive, and "ts" a tissue-specific promoter. tTS- and rtTA-binding sites (tet $O$ ) are shown as gray boxes, an internal ribosome entry sequence as a hatched box and polyA sites as $\perp$. Insulators derived from the chicken HS4 element are depicted as arrow heads.

allows its insertion into AAV and lentiviral vectors. Autoregulated, bidirectional retroviral vectors combine the advantages of small size, allowing single-step transduction with strict regulation of the gene of interest in the infected target cells. Their disadvantage is that they lose the rheostat-type graded response to intermediate concentrations of the effector molecule. Instead, autoregulated expression leads to a bimodal, On/Off expression response $(12,127)$.

A third source of leakiness is intrinsic to the minimal promoter used. Here, careful selection can help to avoid leaky transgene expression. A recent example of several Tet-controlled minimal promoters in a T-cell line demonstrated the mouse mammary tumor virus long terminal repeat (LTR) promoter-derived minimal promoter and the ClonTech-distributed minimal promoter TREtight showed no intrinsic leakiness when flanked by chromatin insulators and driven by a second-generation reverse transactivator (39).

\section{Multiple Gene Expression Systems}

Many of the examples mentioned in the third section require more than one TF to be expressed before full differentiation can be achieved. Expression of two genes in an independent manner can be obtained with the Tet system, but only if one of the transregulators is of the 
Tet-Off type, that is, requiring the constant presence of effectors to prevent transgene expression $(10,102)$. This is not advisable for reasons mentioned above. We therefore recommend the combined use of several of the many published artificial regulatory systems to achieve independent multigene expression control. Streptogramin(PIP-ON) and macrolide-responsive (E-ON) expression units utilize a KRAB repression domain to control gene expression [reviewed in (206)]. They will therefore have the same advantages and disadvantages as tTS-regulated systems. Other On-type inducible gene expression units that have been used in vivo and in gene therapy applications include (i) the dimerizer system (97), which exploits chemically induced heterodimer formation to activate gene expression; (ii) modified steroid receptors and synthetic steroid analogs like mifepristone and tamoxifen $(173,192)$; and (iii) gene switches employing the insectspecific ecdysone receptor (48).

Taken together, the tools for guiding differentiation of stem/progenitor cells after their transplantation are available. These tools are likely to be particularly useful for stem cell-based cell replacement therapy in conditions where current protocols for postgrafting survival and predictable differentiation to desired cell types are unsatisfactory.

\section{APPLICATION OF THE TET SYSTEM IN STEM CELL RESEARCH}

The Tet system has been used successfully for the inducible expression of transgenes in many cell types, with more than 150 publications describing its application in different types of stem cells, thereby impressively demonstrating its potency as an artificial regulatory system. Within the scope of this review, we therefore cannot provide an extensive analysis, but will rather give a brief overview, focusing on a few important aspects, of Tet system regulation.

In reprogramming $(73,74,118,182,207)$ and transdifferentiation $(151,201)$ experiments, DOX-inducible lentiviral vectors were employed to alter cell fate. This approach uses a sole Tet-transactivator to drive all transcription factor expressing units, so their expression is not independent and cannot be used to further dissect the individual expression profile for each factor.

Inducible expression of either GFP or the phosphatidylinositol-glycan complementation class A gene $(P I G-A)$, a gene involved in the synthesis of glycosylphosphatidylinositol-anchored proteins (GPI-APs) on the cell surface, was introduced in hESCs by a tTS-based transsilencing approach similar to the one presented in Figure 2A (222). The authors used a two-vector system to regulate expression of the reporter or the cellular gene. They demonstrated reversible induction of transgene expression in the hESC lines H1 and H9. They also noted that transgene expression was not fully restored after DOX addition to tTS-silenced cells. Both the number of cells responding to DOX treatment (frequently 50\%) and the level of transgene expression were affected, in agreement with the concerns voiced above against using a KRAB-based tTS variant.

Recent publications, in vitro $(176)$ and in vivo $(2,99)$, demonstrate how the Tet system can be used in directed differentiation protocols using single transcription factors. DOX-induced expression of Ngn3 in ESCs that had been chemically predifferentiated to pancreas progenitors greatly enhanced their potential to differentiate into bona fide endocrine pancreas cells, although, to achieve terminal differentiation, the restoration of normal glucose levels, withdrawal of bone morphogenetic protein 4 (BMP4) and fibroblast growth factor 10 (Fgf10), and inclusion of nicotinamide were still required (176). This highlights several important points for in vivo guided differentiation. First, genetically modified ESCs can be chemically differentiated to a still fairly undifferentiated progenitor population. Second, Ngn3 expression greatly improved the further differentiation to pancreatic endocrine cells but was still not sufficient. One or maybe more transcription factors are still needed to achieve a fully cell autonomous differentiation from the progenitor stage. The in vivo proof of principle for such an approach was recently demonstrated by the successful generation of a specific type of sensory neurons-nociceptors-guided by Tet-controlled expression of the diversification factor runt-related transcription factor $1 \mathrm{~b}$ (Runx $1 \mathrm{~b}$ ) specifically in Sox10-expressing neural crest stem cells transplanted to the dorsal root ganglion cavity. Forced expression of Runx $1 b$ strongly increased transplant survival in the enriched neurotrophic environment of the dorsal root ganglion cavity and was sufficient to guide differentiation of boundary neural crest stem cells (bNCSCs) toward a nonpeptidergic nociceptive sensory neuron phenotype both in vitro and in vivo after transplantation (2).

To establish protocols for controlled differentiation of stem cells after transplantation (Fig. 4), it is first advisable to identify in vitro the optimal combination of transcription factors that, after induced activation, will drive un- or predifferentiated donor cells to fully functional cells once they have been equipped with drug-inducible regulatory systems controlling the factors previously identified. In vivo the protocol derived from these experiments will have to be tested and, most likely, modified following transplantation to small and large animals models for the relevant disorder(s) as we cannot predict all possible interactions in and with the host organism. But the prior in vitro validation is still necessary, because our approach aims at uncoupling stem or progenitor cell differentiation from the influence of extrinsic factors present in the host's cellular environment at the transplantation site. It is therefore 


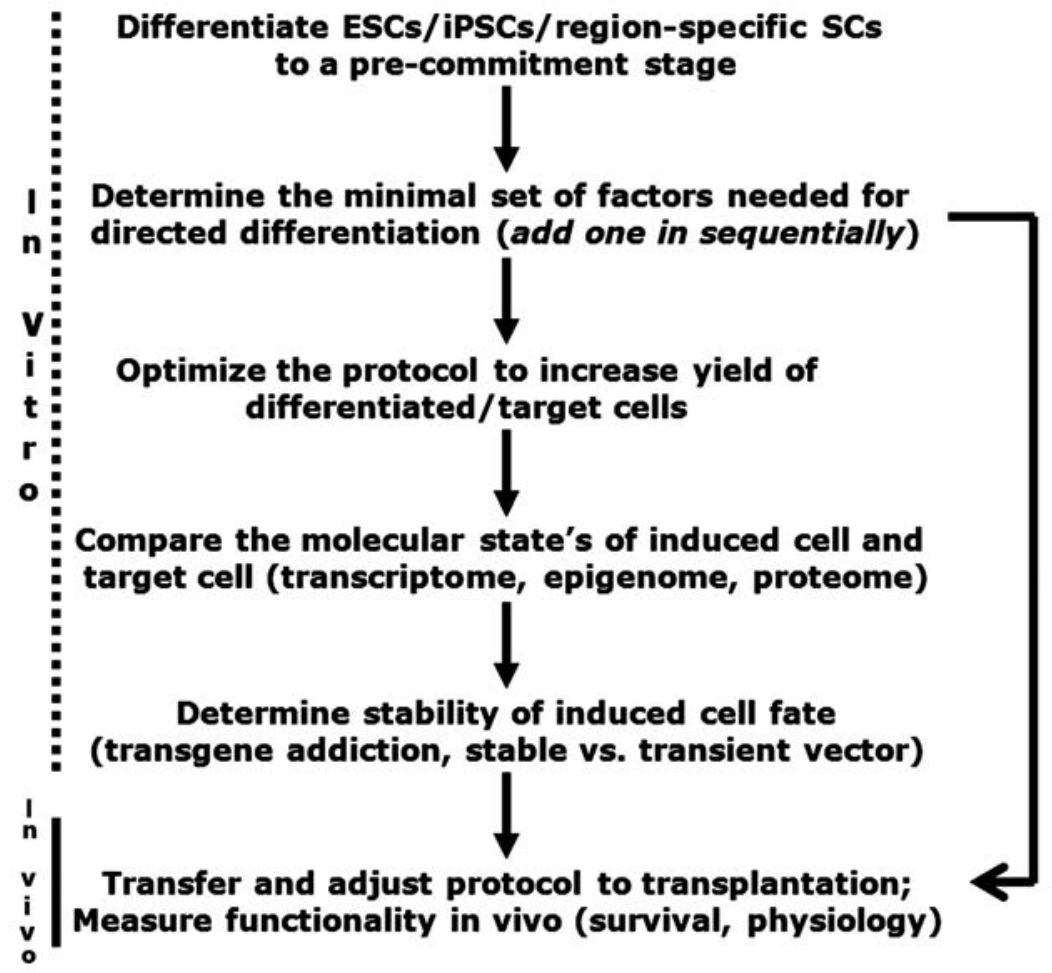

Figure 4. Flowchart for setting up an in vivo directed cell differentiation study. The individual steps to be taken are indicated from top to bottom including the environment in which they should be undertaken. A shortcut from in vitro to in vivo work that can be started in parallel is highlighted on the right by an arrow. Adapted and extended from (27).

essential to recapitulate the differentiation process in vitro both in terms of the specific transcription factors expressed and their temporal relationship, as well as the levels of their expression, since their quantities may influence their impact on the differentiation process (122).

\section{CONCLUSION}

Several recent publications have shown that differentiation to the desired type of cells can be accomplished by expressing a limited number of TFs. Thus, the differentiation of dopaminergic neurons was successful after induced expression of Lmx1a (51), $\beta$-cell differentiation was achieved by expressing Ngn3, Pdx1, and Mafa (224), differentiation of neural crest stem cells toward nociceptor neurons was realized by forced expression of Runx $1 \mathrm{~b}$ in Sox10-expressing cells (2) and motor neurons were generated from human spinal cord derived stem/progenitor cells by ectopic expression of Runx1 (99). A consensus is beginning to emerge from several different fields of research that using regulated gene expression with druginducible systems is a promising experimental approach to differentiate stem cells in vivo after their transplantation. The practical utilization of this method in cell replacement therapy requires on the one hand the development of controlled guidance protocols for directed stem cell differentiation and on the other hand efficient methods of gene transfer into the stem cells and for delivery of the transfected material into the host. Once these goals have been met, this method can become an indispensable tool in regenerative medicine.

ACKNOWLEDGMENTS: This review was funded by the Swedish Research Council, project 20716, Stiftelsen Olle Engkvist Byggare and Signhild Engkvist Stiftelse and German Research Foundation (DFG) for support through SFB473/D6. The authors declare no conflicts of interest.

\section{REFERENCES}

1. Ackermann, A. M.; Gannon, M. Molecular regulation of pancreatic $\beta$-cell mass development, maintenance, and expansion. J. Mol. Endocrinol. 38(1-2):193-206; 2007.

2. Aldskogius, H.; Berens, C.; Kanaykina, N.; Liakhovitskaia, A.; Medvinsky,A.; Sandelin, M.; Schreiner, S.; Wegner, M.; Hjerling-Leffler, J.; Kozlova, E. N. Regulation of boundary cap neural crest stem cell differentiation after transplantation. Stem Cells 27(7):1592-1603; 2009.

3. Anastassiadis, K.; Kim, J.; Daigle, N.; Sprengel, R.; Schöler, H. R.; Stewart, A. F. A predictable ligand regulated expression strategy for stably integrated transgenes in mammalian cells in culture. Gene 298(2):159-172; 2002.

4. Andersson, E. K.; Irvin, D. K.; Ahlsio, J.; Parmar, M. Ngn2 and Nurr1 act in synergy to induce midbrain dopaminergic 
neurons from expanded neural stem and progenitor cells. Exp. Cell Res. 313(6):1172-1180; 2007.

5. Andres, R. H.; Horie, N.; Slikker, W.; Keren-Gill, H.; Zhan, K.; Sun, G.; Manley, N. C.; Pereira, M. P.; Sheikh, L. A.; McMillan, E. L.; Schaar, B. T.; Svendsen, C. N.; Bliss, T. M.; Steinberg, G. K. Human neural stem cells enhance structural plasticity and axonal transport in the ischaemic brain. Brain 134(6):1777-1789; 2011.

6. Antonitsis, P.; Ioannidou-Papagiannaki, E.; Kaidoglou, A.; Charokopos, N.; Kalogeridis, A.; Kouzi-Koliakou, K.; Kyriakopoulou, I.; Klonizakis, I.; Papakonstantinou, C. Cardiomyogenic potential of human adult bone marrow mesenchymal stem cells in vitro. Thorac. Cardiovasc. Surg. 56(2):77-82; 2008.

7. Ayyanathan, K.; Lechner, M. S.; Bell, P.; Maul, G. G.; Schultz, D. C.; Yamada, Y.; Tanaka, K.; Torigoe, K.; Rauscher, $3^{\text {rd }}$, F. J. Regulated recruitment of HP1 to a euchromatic gene induces mitotically heritable, epigenetic gene silencing: A mammalian cell culture model of gene variegation. Genes Dev. 17(15):1855-1869; 2003.

8. Baharvand, H.; Jafary, H.; Massumi, M.; Ashtiani, S. K. Generation of insulin-secreting cells from human embryonic stem cells. Dev. Growth Differ. 48(5):323-332; 2006.

9. Bakshi, A.; Keck, C. A.; Koshkin, V. S.; LeBold, D. G.; Siman, R.; Snyder, E. Y.; McIntosh, T. K. Caspasemediated cell death predominates following engraftment of neural progenitor cells into traumatically injured rat brain. Brain Res. 1065 (1-2):8-19; 2005.

10. Baron, U.; Schnappinger, D.; Helbl, V.; Gossen, M.; Hillen, W.; Bujard, H. Generation of conditional mutants in higher eukaryotes by switching between the expression of two genes. Proc. Natl. Acad. Sci. USA 96(3):1013-1018; 1999.

11. Basson, C. T.; Bachinsky, D. R.; Lin, R. C.; Levi, T.; Elkins, J. A.; Soults, J.; Grayzel, D.; Kroumpouzou, E.; Traill, T. A.; Leblanc-Straceski, J.; Renault, B.; Kucherlapati, R.; Seidman, J. G.; Seidman, C. E. Mutations in human TBX5 cause limb and cardiac malformation in Holt-Oram syndrome. Nat. Genet. 15(1):30-35; 1997.

12. Becskei, A.; Séraphin, B.; Serrano, L. Positive feedback in eukaryotic gene networks: Cell differentiation by graded to binary response conversion. EMBO J. 20(10):25282535; 2001.

13. Benninger, F.; Beck, H.; Wernig, M.; Tucker, K. L.; Brüstle, O.; Scheffler, B. Functional integration of embryonic stem cell-derived neurons in hippocampal slice cultures. J. Neurosci. 23(18):7075-7083; 2003.

14. Ben-Yehudah, A.; White, C.; Navara, C. S.; Castro, C. A.; Ize-Ludlow, D.; Shaffer, B.; Sukhwani, M.; Mathews, C. E.; Chaillet, J. R.; Witchel, S. F. Evaluating protocols for embryonic stem cell differentiation into insulin-secreting $\beta$-cells using insulin II-GFP as a specific and noninvasive reporter. Cloning Stem Cells 11(2):245-257; 2009.

15. Beqqali, A.; van Eldik, W.; Mummery, C.; Passier, R. Human stem cells as a model for cardiac differentiation and disease. Cell. Mol. Life Sci. 66(5):800-813; 2009.

16. Berendse, H. W.; Ponsen, M. M. Detection of preclinical Parkinson's disease along the olfactory trac(t). J. Neural. Transm. Suppl. 70:321-325; 2006.

17. Berens, C.; Hillen, W. Gene regulation by tetracyclines. Constraints of resistance regulation in bacteria shape TetR for application in eukaryotes. Eur. J. Biochem. 270:31093121; 2003.

18. Bissonnette, C. J.; Lyass, L.; Bhattacharyya, B. J.; Belmadani, A.; Miller, R. J.; Kessler, J. A. The controlled generation of functional basal forebrain cholinergic neurons from human embryonic stem cells. Stem Cells 29(5):802-811; 2011.

19. Bohl, D.; Liu, S.; Blanchard, S.; Hocquemiller, M.; Haase, G.; Heard, J. M. Directed evolution of motor neurons from genetically engineered neural precursors. Stem Cells 26(10):2564-2575; 2008.

20. Braam, S. R.; Passier, R.; Mummery, C. L. Cardiomyocytes from human pluripotent stem cells in regenerative medicine and drug discovery. Trends Pharmacol. Sci. 30(10):536-545; 2009.

21. Brederlau, A.; Correia, A. S.; Anisimov, S. V.; Elmi, M.; Paul, G.; Roybon, L.; Morizane, A.; Bergquist, F.; Riebe, I.; Nannmark, U.; Carta, M.; Hanse, E.; Takahashi, J.; Sasai, Y.; Funa, K.; Brundin, P.; Eriksson, P. S.; Li, J. Y. Transplantation of human embryonic stem cell-derived cells to a rat model of Parkinson's disease: Effect of in vitro differentiation on graft survival and teratoma formation. Stem Cells 24(6):1433-1440; 2006.

22. Brüstle, O.; Jones, K. N.; Learish, R. D.; Karram, K.; Choudhary, K.; Wiestler, O. D.; Duncan, I. D.; McKay, R. D. Embryonic stem cell-derived glial precursors: A source of myelinating transplants. Science 285(5428): 754-756; 1999.

23. Bull, N. D.; Martin, K. R. Using stem cells to mend the retina in ocular disease. Regen. Med. 4(6):855-864; 2009.

24. Burns, T. C.; Verfaillie, C. M.; Low, W. C. Stem cells for ischemic brain injury: A critical review. J. Comp. Neurol. 515(1):125-144; 2009.

25. Campanelli, J. T.; Sandrock, R. W.; Wheatley, W.; Xue, H.; Zheng, J.; Liang, F.; Chesnut, J. D.; Zhan, M.; Rao, M. S.; Liu, Y. Expression profiling of human glial precursors. BMC Dev. Biol. 8:102; 2008.

26. Cao, Q. L.; Zhang, Y. P.; Howard, R. M.; Walters, W. M.; Tsoulfas, P.; Whittemore, S. R. Pluripotent stem cells engrafted into the normal or lesioned adult rat spinal cord are restricted to a glial lineage. Exp. Neurol. 167(1):48-58; 2001.

27. Chambers, S. M.; Studer, L. Cell fate plug and play: Direct reprogramming and induced pluripotency. Cell 145(6):827-830; 2011.

28. Chan, E. M.; Ratanasirintrawoot, S.; Park, I. H.; Manos, P. D.; Loh, Y. H.; Huo, H.; Miller, J. D.; Hartung, O.; Rho, J.; Ince, T. A.; Daley, G. Q.; Schlaeger, T. M. Live cell imaging distinguishes bona fide human iPS cells from partially reprogrammed cells. Nat. Biotechnol. 27(11):1033-1037; 2009.

29. Chen, S.; Borowiak, M.; Fox, J. L.; Maehr, R.; Osafune, K.; Davidow, L.; Lam, K.; Peng, L. F.; Schreiber, S. L.; Rubin, L. L.; Melton, D. A small molecule that directs differentiation of human ESCs into the pancreatic lineage. Nat. Chem. Biol. 5(4):258-265; 2009.

30. Cho, M. S.; Lee, Y. E.; Kim, J. Y.; Chung, S.; Cho, Y. H.; Kim, D. S.; Kang, S. M.; Lee, H.; Kim, M. H.; Kim, J. H.; Leem, J. W.; Oh, S. K.; Choi, Y. M.; Hwang, D. Y.; Chang, J. W.; Kim, D. W. Highly efficient and large-scale generation of functional dopamine neurons from human embryonic stem cells. Proc. Natl. Acad. Sci. USA 105(9):3392-3397; 2008.

31. Choi, S. C.; Shim, W. J.; Lim, D. S. Specific monitoring of cardiomyogenic and endothelial differentiation by dual promoter-driven reporter systems in bone marrow mesenchymal stem cells. Biotechnol. Lett. 30(5):835-843; 2008.

32. Christoforou, N.; Miller, R. A.; Hill, C. M.; Jie, C. C.; McCallion, A. S.; Gearhart, J. D. Mouse ES cell-derived cardiac precursor cells are multipotent and facilitate 
identification of novel cardiac genes. J. Clin. Invest. 118(3):894-903; 2008.

33. Clackson, T. Regulated gene expression systems. Gene Ther. 7(2):120-125; 2000.

34. Cobos, I.; Calcagnotto, M. E.; Vilaythong, A. J.; Thwin, M. T.; Noebels, J. L.; Baraban, S. C.; Rubenstein, J. L. Mice lacking Dlx 1 show subtype-specific loss of interneurons, reduced inhibition and epilepsy. Nat. Neurosci. 8(8):1059-1068; 2005.

35. Collombat, P.; Xu, X.; Ravassard, P.; Sosa-Pineda, B.; Dussaud, S.; Billestrup, N.; Madsen, O. D.; Serup, P.; Heimberg, H.; Mansouri, A. The ectopic expression of Pax4 in the mouse pancreas converts progenitor cells into $\alpha$ - and subsequently $\beta$-cells. Cell 138(3):449-462; 2009.

36. Corti, S.;Locatelli, F.;Papadimitriou, D.; Donadoni, C.;Del Bo, R.; Fortunato, F.; Strazzer, S.; Salani, S.; Bresolin, N.; Comi, G. P. Multipotentiality, homing properties, and pyramidal neurogenesis of CNS-derived LeX (ssea-1) + CXCR4+ ${ }^{+}$stem cells. FASEB J. 19(13):1860-1862; 2005.

37. D'Amour, K. A.; Agulnick, A. D.; Eliazer, S.; Kelly, O. G.; Kroon, E.; Baetge, E. E. Efficient differentiation of human embryonic stem cells to definitive endoderm. Nat. Biotechnol. 23(12):1534-1541; 2005.

38. D'Amour, K. A.; Bang, A. G.; Eliazer, S.; Kelly, O. G.; Agulnick, A. D.; Smart, N. G.; Moorman, M.A.; Kroon, E.; Carpenter, M. K.; Baetge, E. E. Production of pancreatic hormone-expressing endocrine cells from human embryonic stem cells. Nat. Biotechnol. 24(11):1392-1401; 2006.

39. Danke, C.; Grünz, X.; Wittmann, J.; Schmidt, A.; AghaMohammadi, S.; Kutsch, O.; Jäck, H.-M.; Hillen, W.; Berens, C. Adjusting transgene expression levels in lymphocytes with a set of inducible promoters. J. Gene Med. 12(6):501-515; 2010.

40. D'Apolito, D.; Baiamonte, E.; Bagliesi, M.; Di Marzo, R.; Calzolari, R.; Ferro, L.; Franco, V.; Spinelli, G.; Maggio, A.; Acuto, S. The sea urchin sns5 insulator protects retroviral vectors from chromosomal position effects by maintaining active chromatin structure. Mol. Ther. 17(8):1434-1441; 2009.

41. Demeterco, C.; Hao, E.; Lee, S. H.; Itkin-Ansari, P.; Levine, F. Adult human $\beta$-cell neogenesis? Diabetes Obes. Metab. 11(Suppl 4):46-53; 2009.

42. Dubois-Dauphin, M.; Julien, S. Stem cell-derived neurons grafted in the striatum are expelled out of the brain after chronic cortical stroke. Stroke 41(8):1807-1814; 2010.

43. Dunnett, S. B.; Björklund, A. Dissecting embryonic neural tissues for transplantation. In: Dunnett, S. B.; Boulton, A. A.; Baker, G. B., eds. Neural Transplantation Methods. Totowa, NJ: Humana Press; 2000:3-25.

44. Edgerton, V. R.; Kim, S. J.; Ichiyama, R. M.; Gerasimenko, Y. P.; Roy, R. R. Rehabilitative therapies after spinal cord injury. J. Neurotrauma 23(3-4):560-570; 2006.

45. Elkabetz, Y.; Panagiotakos, G.; Al Shamy, G.; Socci, N. D.; Tabar, V.; Studer, L. Human ES cell-derived neural rosettes reveal a functionally distinct early neural stem cell stage. Genes Dev. 22(2):152-165; 2008.

46. Englund, U.; Björklund, A.; Wictorin, K.; Lindvall, O.; Kokaia, M. Grafted neural stem cells develop into functional pyramidal neurons and integrate into host cortical circuitry. Proc. Natl. Acad. Sci. USA 99(26):1708917094; 2002.

47. Eriksson, C.; Björklund, A.; Wictorin, K. Neuronal differentiation following transplantation of expanded mouse neurosphere cultures derived from different embryonic forebrain regions. Exp. Neurol. 184(2):615-635; 2003.

48. Esengil, H.; Chang, V.; Mich, J. K.; Chen, J. K. Smallmolecule regulation of zebrafish gene expression. Nat. Chem. Biol. 3(3):154-155; 2007.

49. Evans-Molina, C.; Vestermark, G. L.; Mirmira, R. G. Development of insulin-producing cells from primitive biologic precursors. Curr. Opin. Organ Transplant. 14(1):56-63; 2009.

50. Frank, A. M.; Barker, C. F.; Markmann, J. F. Comparison of whole organ pancreas and isolated islet transplantation for type 1 diabetes. Adv. Surg. 39:137-163; 2005.

51. Friling, S.; Andersson, E.; Thompson, L. H.; Jonsson, M. E.; Hebsgaard, J. B.; Nanou, E.; Alekseenko, Z.; Marklund, U.; Kjellander, S.; Volakakis, N.; Hovatta, O.; El Manira, A.; Björklund, A.; Perlmann, T.; Ericson, J. Efficient production of mesencephalic dopamine neurons by Lmx 1a expression in embryonic stem cells. Proc. Natl. Acad. Sci. USA 106(18):7613-7618; 2009.

52. Fukushima, S.; Coppen, S. R.; Lee, J.; Yamahara, K.; Felkin, L. E.; Terracciano, C. M.; Barton, P. J.; Yacoub, M. H.; Suzuki, K. Choice of cell-delivery route for skeletal myoblast transplantation for treating postinfarction chronic heart failure in rat. PLoS One 3(8): e3071; 2008

53. Gai, H.; Leung, E. L.; Costantino, P. D.; Aguila, J. R.; Nguyen, D. M.; Fink, L. M.; Ward, D. C.; Ma, Y. Generation and characterization of functional cardiomyocytes using induced pluripotent stem cells derived from human fibroblasts. Cell Biol. Int. 33(11):1184-1193; 2009.

54. Gao, J.; Coggeshall, R. E.; Chung, J. M.; Wang, J.; Wu, P. Functional motoneurons develop from human neural stem cell transplants in adult rats. Neuroreport 18(6):565$569 ; 2007$.

55. Garg, V.; Kathiriya, I. S.; Barnes, R.; Schluterman, M. K.; King, I. N.; Butler, C. A.; Rothrock, C. R.; Eapen, R. S.; Hirayama-Yamada, K.; Joo, K.; Matsuoka, R.; Cohen, J. C.; Srivastava, D. GATA4 mutations cause human congenital heart defects and reveal an interaction with TBX5. Nature 424(6947):443-447; 2003.

56. Ge, D.; Liu, X.; Li, L.; Wu, J.; Tu, Q.; Shi, Y.; Chen, H. Chemical and physical stimuli induce cardiomyocyte differentiation from stem cells. Biochem. Biophys. Res. Commun. 381(3):317-321; 2009.

57. Givogri, M. I.; Bottai, D.; Zhu, H. L.; Fasano, S.; Lamorte, G.; Brambilla, R.; Vescovi, A.; Wrabetz, L.; Bongarzone, E. Multipotential neural precursors transplanted into the metachromatic leukodystrophy brain fail to generate oligodendrocytes but contribute to limit brain dysfunction. Dev. Neurosci. 30(5):340$357 ; 2008$.

58. Goncalves, M. A.; Janssen, J. M.; Nguyen, Q. G.; Athanasopoulos, T.; Hauschka, S. D.; Dickson, G.; de Vries, A. A. Transcription factor rational design improves directed differentiation of human mesenchymal stem cells into skeletal myocytes. Mol. Ther. 19(7):1331-1341; 2011.

59. Gossen, M.; Bujard, H. Studying gene function in eukaryotes by conditional gene inactivation. Annu. Rev. Genet. $36: 153-173 ; 2002$.

60. Gross, C.; Zhuang, X.; Stark, K.; Ramboz, S.; Oosting, R.; Kirby, L.; Santarelli, L.; Beck, S.; Hen, R. Serotonin receptor acts during development to establish normal anxiety-like behaviour in the adult. Nature 416(6879): 396-400; 2002. 
61. Guillemot, F. Cell fate specification in the mammalian telencephalon. Prog. Neurobiol. 83(1):37-52; 2007.

62. Guo, T.; Hebrok, M. Stem cells to pancreatic $\beta$-cells: New sources for diabetes cell therapy. Endocr. Rev. 30(3):214$227 ; 2009$

63. Gwak, S. J.; Bhang, S. H.; Yang, H. S.; Kim, S. S.; Lee, D. H.; Lee, S. H.; Kim, B. S. In vitro cardiomyogenic differentiation of adipose-derived stromal cells using transforming growth factor- $\beta 1$. Cell Biochem. Funct. 27(3):148-154; 2009.

64. Hackl, C.; Papazoglou, A.; Ganser, C.; Klein, A.; Prakash, N.; Wurst, W.; Nikkhah, G. Ectopic dopaminergic progenitor cells from En $1^{+/ O t x 2 l a c z}$ transgenic mice survive and functionally reinnervate the striatum following transplantation in a rat model of Parkinson's disease. Cell Transplant. 19(9):1085-1101; 2011.

65. Heikkilä, T. J.; Ylä-Outinen, L.; Tanskanen, J. M.; Lappalainen, R. S.; Skottman, H.; Suuronen, R.; Mikkonen, J. E.; Hyttinen, J. A.; Narkilahti, S. Human embryonic stem cell-derived neuronal cells form spontaneously active neuronal networks in vitro. Exp. Neurol. 218(1):109-116; 2009.

66. Hendry, 2nd., S. L.; van der Bogt, K. E.; Sheikh, A. Y.; Arai, T.; Dylla, S. J.; Drukker, M.; McConnell, M. V.; Kutschka, I.; Hoyt, G.; Cao, F.; Weissman, I. L.; Connolly, A. J.; Pelletier, M. P.; Wu, J. C.; Robbins, R. C.; Yang, P. C. Multimodal evaluation of in vivo magnetic resonance imaging of myocardial restoration by mouse embryonic stem cells. J. Thorac. Cardiovasc. Surg. 136(4): 1028-1037; 2008.

67. Herr, R.; Wöhrle, F. U.; Danke, C.; Berens, C.; Brummer, T. A novel MCF-10A line allowing conditional oncogene expression in 3D culture. Cell Commun. Signal. 9:17; 2011.

68. Herrera, D. G.; Garcia-Verdugo, J. M.; Alvarez-Buylla, A. Adult-derived neural precursors transplanted into multiple regions in the adult brain. Ann. Neurol. 46(6):867$877 ; 1999$.

69. Hevner, R. F.; Hodge, R. D.; Daza, R. A.; Englund, C. Transcription factors in glutamatergic neurogenesis: Conserved programs in neocortex, cerebellum, and adult hippocampus. Neurosci. Res. 55(3):223-233; 2006.

70. Hicks, A. U.; Lappalainen, R. S.; Narkilahti, S.; Suuronen, R.; Corbett, D.; Sivenius, J.; Hovatta, O.; Jolkkonen, J. Transplantation of human embryonic stem cell-derived neural precursor cells and enriched environment after cortical stroke in rats: Cell survival and functional recovery. Eur. J. Neurosci. 29(3):562-574; 2009.

71. Hirabayashi, Y.; Gotoh, Y. Stage-dependent fate determination of neural precursor cells in mouse forebrain. Neurosci. Res. 51(4):331-336; 2005.

72. Hirabayashi, Y.; Suzki, N.; Tsuboi, M.; Endo, T. A.; Toyoda, T.; Shinga, J.; Koseki, H.; Vidal, M.; Gotoh, Y. Polycomb limits the neurogenic competence of neural precursor cells to promote astrogenic fate transition. Neuron 63(5):600-613; 2009.

73. Hockemeyer, D.; Soldner, F.; Beard, C.; Gao, Q.; Mitalipova, M.; DeKelver, R. C.; Katibah, G. E.; Amora, R.; Boydston, E. A.; Zeitler, B.; Meng, X.; Miller, J. C.; Zhang, L.; Rebar, E. J.; Gregory, P. D.; Urnov, F. D.; Jaenisch, R. Efficient targeting of expressed and silent genes in human ESCs and iPSCs using zinc-finger nucleases. Nat. Biotechnol. 27(9):851-857; 2009.

74. Hockemeyer, D.; Soldner, F.; Cook, E. G.; Gao, Q.; Mitalipova, M.; Jaenisch, R. A drug-inducible system for direct reprogramming of human somatic cells to pluripotency. Cell Stem Cell 3(3):346-353; 2008.

75. Hovakimyan, M.; Haas, S. J.; Schmitt, O.; Gerber, B.; Wree, A.; Andressen, C. Mesencephalic human neural progenitor cells transplanted into the adult hemiparkinsonian rat striatum lack dopaminergic differentiation but improve motor behavior. Cells Tissues Organs 188(4):373$383 ; 2008$.

76. Hsu, Y. C.; Lee, D. C.; Chiu, I. M. Neural stem cells, neural progenitors, and neurotrophic factors. Cell Transplant. 16(2):133-150; 2007.

77. Hu, B. Y.; Zhang, S. C. Differentiation of spinal motor neurons from pluripotent human stem cells. Nat. Protoc. 4(9):1295-1304; 2009.

78. Ideguchi, M.; Shinoyama, M.; Gomi, M.; Hayashi, H.; Hashimoto, N.; Takahashi, J. Immune or inflammatory response by the host brain suppresses neuronal differentiation of transplanted ES cell-derived neural precursor cells. J. Neurosci. Res. 86(9):1936-1943; 2008.

79. Idelson, M.; Alper, R.; Obolensky, A.; Ben-Shushan, E.; Hemo, I.; Yachimovich-Cohen, N.; Khaner, H.; Smith, Y.; Wiser, O.; Gropp, M.; Cohen, M. A.; Even-Ram, S.; Berman-Zaken, Y.; Matzrafi, L.; Rechavi, G.; Banin, E.; Reubinoff, B. Directed differentiation of human embryonic stem cells into functional retinal pigment epithelium cells. Cell Stem Cell 5(4):396-408; 2009.

80. Ieda, M.; Fu, J. D.; Delgado-Olguin, P.; Vedantham, V.; Hayashi, Y.; Bruneau, B. G.; Srivastava, D. Direct reprogramming of fibroblasts into functional cardiomyocytes by defined factors. Cell 142(3):375-386; 2010.

81. Jacobs, F. M.; van Erp, S.; van der Linden, A. J.; von Oerthel, L.; Burbach, J. P.; Smidt, M. P. Pitx3 potentiates Nurr1 in dopamine neuron terminal differentiation through release of SMRT-mediated repression. Development 136(4):531-540; 2009.

82. Jankovic, J.; Chen, S.; Le, W. D. The role of Nurr1 in the development of dopaminergic neurons and Parkinson's disease. Prog. Neurobiol. 77(1-2):128-138; 2005.

83. Jin, C. X.; Li, W. L.; Xu, F.; Geng, Z. H.; He, Z. Y.; Su, J.; Tao, X. R.; Ding, X. Y.; Wang, X.; Hu, Y. P. Conversion of immortal liver progenitor cells into pancreatic endocrine progenitor cells by persistent expression of $P d x-1$. J. Cell. Biochem. 104(1):224-236; 2008.

84. Jin, J.; Jeong, S. I.; Shin, Y. M.; Lim, K. S.; Shin, H.; Lee, Y. M.; Koh, H. C.; Kim, K. S. Transplantation of mesenchymal stem cells within a poly(lactide-co- $\varepsilon$-caprolactone) scaffold improves cardiac function in a rat myocardial infarction model. Eur. J. Heart Fail. 11(2):147-153; 2009.

85. Joggerst, S. J.; Hatzopoulos, A. K. Stem cell therapy for cardiac repair: Benefits and barriers. Expert Rev. Mol. Med. 11:e20; 2009.

86. Jopling, C.; Boue, S.; Izpisua Belmonte, J. C. Dedifferentiation, transdifferentiation and reprogramming: Three routes to regeneration. Nat. Rev. Mol. Cell Biol. 12(2):79-89; 2011.

87. Kageyama, R.; Ohtsuka, T.; Hatakeyama, J.; Ohsawa, R. Roles of bHLH genes in neural stem cell differentiation. Exp. Cell Res. 306(2):343-348; 2005.

88. Kajiyama, H.; Hamazaki, T. S.; Tokuhara, M.; Masui, S.; Okabayashi, K.; Ohnuma, K.; Yabe, S.; Yasuda, K.; Ishiura, S.; Okochi, H.; Asashima, M. Pdxl-transfected adipose tissue-derived stem cells differentiate into insulin-producing cells in vivo and reduce hyperglycemia in diabetic mice. Int. J. Dev. Biol. 54(4):699-705; 2010. 
89. Kattman, S. J.; Huber, T. L.; Keller, G. M. Multipotent $f l k-1^{+}$cardiovascular progenitor cells give rise to the cardiomyocyte, endothelial, and vascular smooth muscle lineages. Dev. Cell 11(5):723-732; 2006.

90. Keirstead, H. S.; Nistor, G.; Bernal, G.; Totoiu, M.; Cloutier, F.; Sharp, K.; Steward, O. Human embryonic stem cell-derived oligodendrocyte progenitor cell transplants remyelinate and restore locomotion after spinal cord injury. J. Neurosci. 25(19):4694-4705; 2005.

91. Kele, J.; Simplicio, N.; Ferri, A. L.; Mira, H.; Guillemot, F.; Arenas, E.; Ang, S. L. Neurogenin 2 is required for the development of ventral midbrain dopaminergic neurons. Development 133(3):495-505; 2006.

92. Kim, D.; Kim, C. H.; Moon, J. I.; Chung, Y. G.; Chang, M. Y.; Han, B. S.; Ko, S.; Yang, E.; Cha, K. Y.; Lanza, R.; Kim, K. S. Generation of human induced pluripotent stem cells by direct delivery of reprogramming proteins. Cell Stem Cell 4(6):472-476; 2009.

93. Kim, D. S.; Kim, J. Y.; Kang, M.; Cho, M. S.; Kim, D. W. Derivation of functional dopamine neurons from embryonic stem cells. Cell Transplant. 16(2):117-123; 2007.

94. Kim, H. J.; Hida, H.; Jung, C. G.; Miura, Y.; Nishino, H. Treatment with deferoxamine increases neurons from neural stem/progenitor cells. Brain Res. 1092(1): $1-15 ; 2006$.

95. Kim, J. B.; Greber, B.; Arauzo-Bravo, M. J.; Meyer, J.; Park, K. I.; Zaehres, H.; Schöler, H. R. Direct reprogramming of human neural stem cells by OCT4. Nature 461(7264):649-653; 2009

96. Kim, J. B.; Sebastiano, V.; Wu, G.; Arauzo-Bravo, M. J.; Sasse, P.; Gentile, L.; Ko, K.; Ruau, D.; Ehrich, M.; van den Boom, D.; Meyer, J.; Hubner, K.; Bernemann, C.; Ortmeier, C.; Zenke, M.; Fleischmann, B. K.; Zaehres, H.; Schöler, H. R. Oct4-induced pluripotency in adult neural stem cells. Cell 136(3):411-419; 2009.

97. Kobinger, G. P.; Deng, S.; Louboutin, J. P.; Vatamaniuk, M.; Rivera, V. M.; Lian, M. M.; Markmann, J. F.; Clackson, T.; Raper, S. E.; Matschinsky, F.; Wilson, J. M. Pharmacologically regulated regeneration of functional human pancreatic islets. Mol. Ther. 11(1):105$111 ; 2005$

98. Kodama, M.; Takeshita, F.; Kanegasaki, S.; Ochiya, T.; Quinn, G. Pancreatic endocrine and exocrine cell ontogeny from renal capsule transplanted embryonic stem cells in streptozocin-injured mice. J. Histochem. Cytochem. 56(1):33-44; 2008

99. König, N.; Akesson, E.; Telorack, M.; Vasylovska, S.; Ngamjariyawat, A.; Sundstrom, E.; Oster, A.; Trolle, C.; Berens, C.; Aldskogius, H.; Seiger, A.; Kozlova, E. N. Forced Runxl expression in human neural stem/progenitor cells transplanted to the rat dorsal root ganglion cavity results in extensive axonal growth specifically from spinal cord-derived neurospheres. Stem Cells Dev. 20(11):1847$1857 ; 2011$

100. Kozubenko, N.; Turnovcova, K.; Kapcalova, M.; Butenko, O.; Anderova, M.; Rusnakova, V.; Kubista, M.; Hampl, A.; Jendelova, P.; Sykova, E. Analysis of in vitro and in vivo characteristics of human embryonic stem cell-derived neural precursors. Cell Transplant. 19(4):471-486; 2010.

101. Kroon, E.; Martinson, L. A.; Kadoya, K.; Bang, A. G.; Kelly, O. G.; Eliazer, S.; Young, H.; Richardson, M.; Smart, N. G.; Cunningham, J.; Agulnick, A. D.; D'Amour, K. A.; Carpenter, M. K.; Baetge, E. E. Pancreatic endoderm derived from human embryonic stem cells generates glucose-responsive insulin-secreting cells in vivo. Nat. Biotechnol. 26(4):443-452; 2008.

102. Krueger, C. Implementing dual regulator setups for conditional gene expression by exploiting the functional flexibility of TetR. Dissertation, Friedrich-AlexanderUniversität Erlangen-Nürnberg; 2004.

103. Kupatt, C.; Horstkötte, J.; Vlastos, G. A.; Pfosser, A.; Lebherz, C.; Semisch, M.; Thalgott, M.; Büttner, K.; Browarzyk, C.; Mages, J.; Hoffmann, R.; Deten, A.; Lamparter, M.; Müller, F.; Beck, H.; Büning, H.; Boekstegers, P.; Hatzopoulos, A. K. Embryonic endothelial progenitor cells expressing a broad range of proangiogenic and remodeling factors enhance vascularization and tissue recovery in acute and chronic ischemia. FASEB J. 19(11):1576-1578; 2005.

104. Kuzmenkin, A.; Liang, H.; Xu, G.; Pfannkuche, K.; Eichhorn, H.; Fatima, A.; Luo, H.; Saric, T.; Wernig, M.; Jaenisch, R.; Hescheler, J. Functional characterization of cardiomyocytes derived from murine induced pluripotent stem cells in vitro. FASEB J. 23(12):4168-4180; 2009.

105. Kwon, C.; Qian, L.; Cheng, P.; Nigam, V.; Arnold, J.; Srivastava, D. A regulatory pathway involving Notch1/ $\beta$-catenin/Isl1 determines cardiac progenitor cell fate. Nat. Cell Biol. 11(8):951-957; 2009.

106. Kwon, Y. D.; Oh, S. K.; Kim, H. S.; Ku, S. Y.; Kim, S. H.; Choi, Y. M.; Moon, S. Y. Cellular manipulation of human embryonic stem cells by TAT-PDX1 protein transduction. Mol. Ther. 12(1):28-32; 2005.

107. Lee, H. S.; Bae, E. J.; Yi, S. H.; Shim, J. W.; Jo, A. Y.; Kang, J. S.; Yoon, E. H.; Rhee, Y. H.; Park, C. H.; Koh, H. C.; Kim, H. J.; Choi, H. S.; Han, J. W.; Lee, Y. S.; Kim, J.; Li, J. Y.; Brundin, P.; Lee, S. H. Foxa2 and Nurr1 synergistically yield A9 nigral dopamine neurons exhibiting improved differentiation, function, and cell survival. Stem Cells 28(3):501-512; 2010

108. Leobon, B.; Garcin, I.; Menasche, P.; Vilquin, J. T.; Audinat, E.; Charpak, S. Myoblasts transplanted into rat infarcted myocardium are functionally isolated from their host. Proc. Natl. Acad. Sci. USA 100(13):7808-7811; 2003.

109. Lévesque, M. F.; Neuman, T.; Rezak, M. Therapeutic microinjection of autologous adult human neural stem cells and differentiated neurons for Parkinson's disease: Five-year post-operative outcome. Open Stem Cell J. $1: 20-29 ; 2009$.

110. Li, W.; Ding, S. Small molecules that modulate embryonic stem cell fate and somatic cell reprogramming. Trends Pharmacol. Sci. 31(1):36-45; 2010.

111. Li, X. J.; Hu, B. Y.; Jones, S. A.; Zhang, Y. S.; Lavaute, T.; Du, Z. W.; Zhang, S. C. Directed differentiation of ventral spinal progenitors and motor neurons from human embryonic stem cells by small molecules. Stem Cells 26(4):886-893; 2008.

112. Liew, C. G.; Shah, N. N.; Briston, S. J.; Shepherd, R. M.; Khoo, C. P.; Dunne, M. J.; Moore, H. D.; Cosgrove, K. E.; Andrews, P. W. PAX4 enhances $\beta$-cell differentiation of human embryonic stem cells. PLoS One 3(3):e1783; 2008.

113. Lin, S.; Xu, J.; Hu, S.; Xu, L.; Zhang, C.; Wang, Y.; Gu, Y. Combined application of neutrophin-3 gene and neural stem cells is ameliorative to delay of denervated skeletal muscular atrophy after tibial nerve transection in rats. Cell Transplant. 20(3):381-390; 2011.

114. Lindvall, O.; Kokaia, Z. Prospects of stem cell therapy for replacing dopamine neurons in Parkinson's disease. Trends Pharmacol. Sci. 30(5):260-267; 2009. 
115. Lunn, J. S.; Sakowski, S. A.; Federici, T.; Glass, J. D.; Boulis, N. M.; Feldman, E. L. Stem cell technology for the study and treatment of motor neuron diseases. Regen. Med. 6(2):201-213; 2011.

116. Mack, G. S. ReNeuron and StemCells get green light for neural stem cell trials. Nat. Biotech. 29(2):95-97; 2011

117. Maehr, R.; Chen, S.; Snitow, M.; Ludwig, T.; Yagasaki, L.; Goland, R.; Leibel, R. L.; Melton, D. A. Generation of pluripotent stem cells from patients with type 1 diabetes. Proc. Natl. Acad. Sci. USA 106(37):15768-15773; 2009.

118. Maherali, N.; Ahfeldt, T.; Rigamonti, A.; Utikal, J.; Cowan, C.; Hochedlinger, K. A high-efficiency system for the generation and study of human induced pluripotent stem cells. Cell Stem Cell 3(3):340-345; 2008.

119. Maherali, N.; Hochedlinger, K. Guidelines and techniques for the generation of induced pluripotent stem cells. Cell Stem Cell 3(6):595-605; 2008.

120. Maire, C. L.; Buchet, D.; Kerninon, C.; Deboux, C.; Baron-Van Evercooren, A.; Nait-Oumesmar, B. Directing human neural stem/precursor cells into oligodendrocytes by overexpression of Olig2 transcription factor. J. Neurosci. Res. 87(15):3438-3446; 2009.

121. Marchand, M.; Schroeder, I. S.; Markossian, S.; Skoudy, A.; Negre, D.; Cosset, F. L.; Real, P.; Kaiser, C.; Wobus, A. M.; Savatier, P. Mouse ES cells over-expressing the transcription factor NeuroD1 show increased differentiation towards endocrine lineages and insulin-expressing cells. Int. J. Dev. Biol. 53(4):569-578; 2009.

122. Marmigère, F.; Ernfors, P. Specification and connectivity of neuronal subtypes in the sensory lineage. Nat. Rev. Neurosci. 8(2):114-127; 2007.

123. Martino, G.; Pluchino, S. The therapeutic potential of neural stem cells. Nat. Rev. Neurosci. 7(5):395-406; 2006.

124. Mato, E.; Lucas, M.; Petriz, J.; Gomis, R.; Novials, A. Identification of a pancreatic stellate cell population with properties of progenitor cells: New role for stellate cells in the pancreas. Biochem. J. 421(2):181-191; 2009.

125. Matsuda, R.; Yoshikawa, M.; Kimura, H.; Ouji, Y.; Nakase, H.; Nishimura, F.; Nonaka, J.; Toriumi, H.; Yamada, S.; Nishiofuku, M.; Moriya, K.; Ishizaka, S.; Nakamura, M.; Sakaki, T. Cotransplantation of mouse embryonic stem cells and bone marrow stromal cells following spinal cord injury suppresses tumor development. Cell Transplant. 18(1):39-54; 2009.

126. Matsuura, K.; Honda, A.; Nagai, T.; Fukushima, N.; Iwanaga, K.; Tokunaga, M.; Shimizu, T.; Okano, T.; Kasanuki, H.; Hagiwara, N.; Komuro, I. Transplantation of cardiac progenitor cells ameliorates cardiac dysfunction after myocardial infarction in mice. J. Clin. Invest. 119(8):2204-2217; 2009.

127. May, T.; Eccleston, L.; Herrmann, S.; Hauser, H.; Goncalves, J.; Wirth, D. Bimodal and hysteretic expression in mammalian cells from a synthetic gene circuit. PLoS One 3(6):e2372; 2008.

128. Mayford, M.; Bach, M. E.; Huang, Y.-Y.; Wang, L.; Hawkins, R. D.; Kandel, E. R. Control of memory formation through regulated expression of a CaMKII transgene. Science 274(5293):1678-1683; 1996.

129. Merscher, S.; Funke, B.; Epstein, J.A.; Heyer, J.; Puech, A.; Lu, M. M.; Xavier, R. J.; Demay, M. B.; Russell, R. G.; Factor, S.; Tokooya, K.; Jore, B. S.; Lopez, M.; Pandita, R. K.; Lia, M.; Carrion, D.; Xu, H.; Schorle, H.; Kobler, J. B.; Scambler, P.; Wynshaw-Boris, A.; Skoultchi, A. I.; Morrow, B. E.; Kucherlapati, R. TBX1 is responsible for cardiovascular defects in velo-cardio-facial/DiGeorge syndrome. Cell 104(4):619-629; 2001.

130. Michalon, A.; Koshibu, K.; Baumgärtel, K.; Spirig, D. H.; Mansuy, I. M. Inducible and neuron-specific gene expression in the adult mouse brain with the rtTA2 $2^{\mathrm{S}}-\mathrm{M} 2$ system. Genesis 43(4):205-212; 2005.

131. Miller, F. D.; Gauthier, A. S. Timing is everything: Making neurons versus glia in the developing cortex. Neuron 54(3):357-369; 2007.

132. Molyneaux, B. J.; Arlotta, P.; Menezes, J. R.; Macklis, J. D. Neuronal subtype specification in the cerebral cortex. Nat. Rev. Neurosci. 8(6):427-437; 2007.

133. Moretti, A.; Caron, L.; Nakano, A.; Lam, J. T.; Bernshausen, A.; Chen, Y.; Qyang, Y.; Bu, L.; Sasaki, M.; Martin-Puig, S.; Sun, Y.; Evans, S. M.; Laugwitz, K. L.; Chien, K. R. Multipotent embryonic is $l^{+}$progenitor cells lead to cardiac, smooth muscle, and endothelial cell diversification. Cell 127(6):1151-1165; 2006.

134. Mori-Uchino, M.; Takeuchi, T.; Murakami, I.; Yano, T.; Yasugi, T.; Taketani, Y.; Nakagawa, K.; Kanda, T. Enhanced transgene expression in the mouse skeletal muscle infected by the adeno-associated viral vector with the human elongation factor $1 \alpha$ promoter and a human chromatin insulator. J. Gene Med. 11(7):598-604; 2009.

135. Muotri, A. R.; Nakashima, K.; Toni, N.; Sandler, V. M.; Gage, F. H. Development of functional human embryonic stem cell-derived neurons in mouse brain. Proc. Natl. Acad. Sci. USA 102(51):18644-18648; 2005.

136. Nagaya, M.; Kubota, S.; Isogai, A.; Tadokoro, M.; Akashi, K. Ductular cell proliferation in islet cell neogenesis induced by incomplete ligation of the pancreatic duct in dogs. Surg. Today 34(7):586-592; 2004.

137. Nakamura, T.; Kinoshita, S. New hopes and strategies for the treatment of severe ocular surface disease. Curr. Opin. Ophthalmol. 22(4):274-278; 2011.

138. Nefzger, C. M.; Haynes, J. M.; Pouton, C. W. Directed expression of Gata2, Mash1, and Foxa2 synergize to induce the serotonergic neuron phenotype during in vitro differentiation of embryonic stem cells. Stem Cells 29(6):928-939; 2011.

139. Noguchi, H.; Oishi, K.; Ueda, M.; Yukawa, H.; Hayashi, S.; Kobayashi, N.; Levy, M. F.; Matsumoto, S. Establishment of mouse pancreatic stem cell line. Cell Transplant. 18(5):563-571; 2009.

140. Nomura, T.; Ueyama, T.; Ashihara, E.; Tateishi, K.; Asada, S.; Nakajima, N.; Isodono, K.; Takahashi, T.; Matsubara, H.; Oh, H. Skeletal muscle-derived progenitors capable of differentiating into cardiomyocytes proliferate through myostatin-independent TGF- $\beta$ family signaling. Biochem. Biophys. Res. Commun. 365(4):863-869; 2008.

141. Okura, H.; Matsuyama, A.; Lee, C. M.; Saga, A.; KakutaYamamoto, A.; Nagao, A.; Sougawa, N.; Sekiya, N.; Takekita, K.; Shudo, Y.; Miyagawa, S.; Komoda, H.; Okano, T.; Sawa, Y. Cardiomyoblast-like cells differentiated from human adipose tissue-derived mesenchymal stem cells improve left ventricular dysfunction and survival in a rat myocardial infarction model. Tissue Eng. Part C Methods 16(3):417-425; 2010.

142. Olson, E. N. Gene regulatory networks in the evolution and development of the heart. Science 313(5795):19221927; 2006.

143. Panman, L.; Andersson, E.; Alekseenko, Z.; Hedlund, E.; Kee, N.; Mong, J.; Uhde, C. W.; Deng, Q.; Sandberg, R.; Stanton, L. W.; Ericson, J.; Perlmann, T. Transcription 
factor-induced lineage selection of stem-cell-derived neural progenitor cells. Cell Stem Cell 8(6):663-675; 2011.

144. Parekh, V. S.; Joglekar, M. V.; Hardikar, A. A. Differentiation of human umbilical cord blood-derived mononuclear cells to endocrine pancreatic lineage. Differentiation 78(4):232-240; 2009.

145. Parish, C. L.; Castelo-Branco, G.; Rawal, N.; Tonnesen, J.; Sorensen, A. T.; Salto, C.; Kokaia, M.; Lindvall, O.; Arenas, E. Wnt5a-treated midbrain neural stem cells improve dopamine cell replacement therapy in parkinsonian mice. J. Clin. Invest. 118(1):149-160; 2008.

146. Park, C. H.; Kang, J. S.; Kim, J. S.; Chung, S.; Koh, J. Y.; Yoon, E. H.; Jo, A. Y.; Chang, M. Y.; Koh, H. C.; Hwang, S.; Suh-Kim, H.; Lee, Y. S.; Kim, K. S.; Lee, S. H. Differential actions of the proneural genes encoding Mash1 and neurogenins in Nurr1-induced dopamine neuron differentiation. J. Cell Sci. 119(11):2310-2320; 2006.

147. Park, I. H.; Lerou, P. H.; Zhao, R.; Huo, H.; Daley, G. Q. Generation of human-induced pluripotent stem cells. Nat. Protoc. 3(7):1180-1186; 2008.

148. Parras, C. M.; Hunt, C.; Sugimori, M.; Nakafuku, M.; Rowitch, D.; Guillemot, F. The proneural gene Mash1 specifies an early population of telencephalic oligodendrocytes. J. Neurosci. 27(16):4233-4242; 2007.

149. Perrier, A. L.; Tabar, V.; Barberi, T.; Rubio, M.E.; Bruses, J.; Topf, N.; Harrison, N. L.; Studer, L. Derivation of midbrain dopamine neurons from human embryonic stem cells. Proc. Natl. Acad. Sci. USA 101(34):12543-12548; 2004.

150. Pfannkuche, K.; Liang, H.; Hannes, T.; Xi, J.; Fatima, A.; Nguemo, F.; Matzkies, M.; Wernig, M.; Jaenisch, R.; Pillekamp, F.; Halbach, M.; Schunkert, H.; Saric, T.; Hescheler, J.; Reppel, M. Cardiac myocytes derived from murine reprogrammed fibroblasts: Intact hormonal regulation, cardiac ion channel expression and development of contractility. Cell. Physiol. Biochem. 24(1-2):73$86 ; 2009$

151. Pfisterer, U.; Kirkeby, A.; Torper, O.; Wood, J.; Nelander, J.; Dufour, A.; Björklund, A.; Lindvall, O.; Jakobsson, J.; Parmar, M. Direct conversion of human fibroblasts to dopaminergic neurons. Proc. Natl. Acad. Sci. USA 108(25):10343-10348; 2011.

152. Piepoli, M. F. Transplantation of progenitor cells and regeneration of damaged myocardium: More facts or doubts? Insights from experimental and clinical studies. J. Cardiovasc. Med. 10(8):624-634; 2009.

153. Pipes, G. C.; Creemers, E. E.; Olson, E. N. The myocardin family of transcriptional coactivators: Versatile regulators of cell growth, migration, and myogenesis. Genes Dev. 20(12):1545-1556; 2006.

154. Pluchino, S.; Quattrini, A.; Brambilla, E.; Gritti, A.; Salani, G.; Dina, G.; Galli, R.; Del Carro, U.; Amadio, S.; Bergami, A.; Furlan, R.; Comi, G.; Vescovi, A. L.; Martino, G. Injection of adult neurospheres induces recovery in a chronic model of multiple sclerosis. Nature 422(6933):688-694; 2003.

155. Poitras, L.; Ghanem, N.; Hatch, G.; Ekker, M. The proneural determinant MASH1 regulates forebrain $D l x 1 / 2$ expression through the $I 12 b$ intergenic enhancer. Development 134(9):1755-1765; 2007.

156. Pruszak, J.; Isacson, O. Molecular and cellular determinants for generating ES-cell derived dopamine neurons for cell therapy. Adv. Exp. Med. Biol. 651:112-123; 2009.

157. Qu, Z.; Thottassery, J. V.; Van Ginkel, S.; Manuvakhova, M.; Westbrook, L.; Roland-Lazenby, C.; Hays, S.; Kern, F. G.
Homogeneity and long-term stability of tetracycline-regulated gene expression with low basal activity by using the rtTA2 $2^{\mathrm{S}}-\mathrm{M} 2$ transactivator and insulator-flanked reporter vectors. Gene 327:61-73; 2004

158. Reçillas-Targa,F.; Valadez-Graham,V.;Farrell,C.M.Prospects and implications of using chromatin insulators in gene therapy and transgenesis. Bioessays 26(7):796-807; 2004.

159. Reinecke, H.; Poppa, V.; Murry, C. E. Skeletal muscle stem cells do not transdifferentiate into cardiomyocytes after cardiac grafting. J. Mol. Cell. Cardiol. 34(2):241$249 ; 2002$.

160. Robey, T. E.; Saiget, M. K.; Reinecke, H.; Murry, C. E. Systems approaches to preventing transplanted cell death in cardiac repair. J. Mol. Cell. Cardiol. 45(4):567-581; 2008.

161. Rodriguez-Gomez, J. A.; Lu, J. Q.; Velasco, I.; Rivera, S.; Zoghbi, S. S.; Liow, J. S.; Musachio, J. L.; Chin, F. T.; Toyama, H.; Seidel, J.; Green, M. V.; Thanos, P. K.; Ichise, M.; Pike, V. W.; Innis, R. B.; McKay, R. D. Persistent dopamine functions of neurons derived from embryonic stem cells in a rodent model of Parkinson disease. Stem Cells 25(4):918-928; 2007.

162. Rosa, A.; Brivanlou, A. H. Synthetic mRNAs: Powerful tools for reprogramming and differentiation of human cells. Cell Stem Cell 7(5):549-550; 2010.

163. Ross, S. E.; Greenberg, M. E.; Stiles, C. D. Basic helixloop-helix factors in cortical development. Neuron 39(1):13-25; 2003.

164. Rovere-Querini, P.; Brunelli, S.; Clementi, E.; Manfredi, A. A. Cell death: Tipping the balance of autoimmunity and tissue repair. Curr. Pharm. Des. 14(3):269-277; 2008.

165. Ryan, E. A.; Bigam, D.; Shapiro, A. M. Current indications for pancreas or islet transplant. Diabetes Obes. Metab. 8(1):1-7; 2006.

166. Ryan, E. A.; Paty, B. W.; Senior, P. A.; Bigam, D.; Alfadhli, E.; Kneteman, N. M.; Lakey, J. R.; Shapiro, A. M. Five-year follow-up after clinical islet transplantation. Diabetes 54(7):2060-2069; 2005.

167. Saijo, K.; Winner, B.; Carson, C. T.; Collier, J. G.; Boyer, L.; Rosenfeld, M. G.; Gage, F. H.; Glass, C. K. A Nurr1/ CoREST pathway in microglia and astrocytes protects dopaminergic neurons from inflammation-induced death. Cell 137(1):47-59; 2009.

168. Sakurai, K.; Osumi, N. The neurogenesis-controlling factor, Pax6, inhibits proliferation and promotes maturation in murine astrocytes. J. Neurosci. 28(18):4604-4612; 2008.

169. Sanchez-Pernaute, R.; Lee, H.; Patterson, M.; ReskeNielsen, C.; Yoshizaki, T.; Sonntag, K. C.; Studer, L.; Isacson, O. Parthenogenetic dopamine neurons from primate embryonic stem cells restore function in experimental Parkinson's disease. Brain 131(8):2127-2139; 2008.

170. Sarkisian, C. J.; Keister, B. A.; Stairs, D. B.; Boxer, R. B.; Moody, S. E.; Chodosh, L. A. Dose-dependent oncogeneinduced senescence in vivo and its evasion during mammary tumorigenesis. Nat. Cell Biol. 9(5):493-505; 2007.

171. Scheffler, B.; Schmandt, T.; Schröder, W.; Steinfarz, B.; Husseini, L.; Wellmer, J.; Seifert, G.; Karram, K.; Beck, H.; Blumcke, I.; Wiestler, O. D.; Steinhauser, C.; Brüstle, O. Functional network integration of embryonic stem cell-derived astrocytes in hippocampal slice cultures. Development 130(22):5533-5541; 2003.

172. Scheffler, B.; Walton, N. M.; Lin, D. D.; Goetz, A. K.; Enikolopov, G.; Roper, S. N.; Steindler, D. A. Phenotypic and functional characterization of adult brain neuropoiesis. Proc. Natl. Acad. Sci. USA 102(26):9353-9358; 2005. 
173. Schillinger, K. J.; Tsai, S. Y.; Taffet, G. E.; Reddy, A. K.; Marian, A. J.; Entman, M. L.; Oka, K.; Chan, L.; O'Malley, B. W. Regulatable atrial natriuretic peptide gene therapy for hypertension. Proc. Natl. Acad. Sci. USA 102(39):13789-13794; 2005.

174. Schott, J. J.; Benson, D. W.; Basson, C. T.; Pease, W.; Silberbach, G. M.; Moak, J. P.; Maron, B. J.; Seidman, C. E.; Seidman, J. G. Congenital heart disease caused by mutations in the transcription factor $N K X 2-5$. Science 281(5373):108-111; 1998.

175. Schroeder, I. S.; Rolletschek, A.; Blyszczuk, P.; Kania, G.; Wobus, A. M. Differentiation of mouse embryonic stem cells to insulin-producing cells. Nat. Protoc. 1(2):495-507; 2006.

176. Serafimidis, I.; Rakatzi, I.; Episkopou, V.; Gouti, M.; Gavalas, A. Novel effectors of directed and Ngn3-mediated differentiation of mouse embryonic stem cells into endocrine pancreas progenitors. Stem Cells 26(1):3-16; 2008

177. Shen, C. C.; Lin, C. H.; Yang, Y. C.; Chiao, M. T.; Cheng, W. Y.; Ko, J. L. Intravenous implanted neural stem cells migrate to injury site, reduce infarct volume, and improve behavior after cerebral ischemia. Curr. Neurovasc. Res. 7(3):167-179; 2010.

178. Shin, E.; Palmer, M. J.; Li, M.; Fricker, R. A. GABAergic neurons from mouse embryonic stem cells possess functional properties of striatal neurons in vitro, and develop into striatal neurons in vivo in a mouse model of Huntington's disease. Stem Cell Rev. 8(2):513-531; 2011.

179. Skuk, D.; Tremblay, J. P. Intramuscular cell transplantation as a potential treatment of myopathies: Clinical and preclinical relevant data. Expert Opin. Biol. Ther. 11(3):359-374; 2011.

180. Smidt, M. P.; Burbach, J. P. Terminal differentiation of mesodiencephalic dopaminergic neurons: The role of Nurr1 and Pitx3. Adv. Exp. Med. Biol. 651:47-57; 2009.

181. Smits, A. M.; van Vliet, P.; Metz, C. H.; Korfage, T.; Sluijter, J. P.; Doevendans, P. A.; Goumans, M. J. Human cardiomyocyte progenitor cells differentiate into functional mature cardiomyocytes: An in vitro model for studying human cardiac physiology and pathophysiology. Nat. Protoc. 4(2):232-243; 2009.

182. Soldner, F.; Hockemeyer, D.; Beard, C.; Gao, Q.; Bell, G. W.; Cook, E. G.; Hargus, G.; Blak, A.; Cooper, O.; Mitalipova, M.; Isacson, O.; Jaenisch, R. Parkinson's disease patient-derived induced pluripotent stem cells free of viral reprogramming factors. Cell 136(5):964-977; 2009.

183. Stadtfeld, M.; Nagaya, M.; Utikal, J.; Weir, G.; Hochedlinger, $\mathrm{K}$. Induced pluripotent stem cells generated without viral integration. Science 322(5903):945-949; 2008.

184. Steel, D.; Hyllner, J.; Sartipy, P. Cardiomyocytes derived from human embryonic stem cells-characteristics and utility for drug discovery. Curr. Opin. Drug Discov. Devel 12(1):133-140; 2009.

185. Stieger, K.; Belbellaa, B.; Le Guiner, C.; Moullier, P.; Rolling, F. In vivo gene regulation using tetracyclineregulatable systems. Adv. Drug Deliv. Rev. 61(7-8):527$541 ; 2009$.

186. Su, H.; Wu, Y.; Yuan, Q.; Guo, J.; Zhang, W.; Wu, W. Optimal time point for neuronal generation of transplanted neural progenitor cells in injured spinal cord following root avulsion. Cell Transplant. 20(2):167-176; 2011.

187. Suter, D. M.; Preynat-Seauve, O.; Tirefort, D.; Feki, A.; Krause, K. H. Phenazopyridine induces and synchronizes neuronal differentiation of embryonic stem cells. J. Cell. Mol. Med. 13(9B):3517-3527; 2009.
188. Suzuki, K.; Murtuza, B.; Beauchamp, J. R.; Smolenski, R. T.; Varela-Carver, A.; Fukushima, S.; Coppen, S. R.; Partridge, T. A.; Yacoub, M. H. Dynamics and mediators of acute graft attrition after myoblast transplantation to the heart. FASEB J. 18(10):1153-1155; 2004.

189. Szabo, E.; Rampalli, S.; Risueno, R. M.; Schnerch, A.; Mitchell, R.; Fiebig-Comyn, A.; Levadoux-Martin, M.; Bhatia, M. Direct conversion of human fibroblasts to multilineage blood progenitors. Nature 468(7323):521526; 2010.

190. Szulc, J.; Wiznerowicz, M.; Sauvain, M. O.; Trono, D.; Aebischer, P. A versatile tool for conditional gene expression and knockdown. Nat. Methods 3(2):109-116; 2006.

191. Takahashi, K.; Okita, K.; Nakagawa, M.; Yamanaka, S. Induction of pluripotent stem cells from fibroblast cultures. Nat. Protoc. 2(12):3081-3089; 2007.

192. Takahashi, K.; Saishin, Y.; Silva, R. L.; Oshima, Y.; Oshima, S.; Melia, M.; Paszkiet, B.; Zerby, D.; Kadan, M. J.; Liau, G.; Kaleko, M.; Connelly, S.; Luo, T.; Campochiaro, P. A. Intraocular expression of endostatin reduces VEGF-induced retinal vascular permeability, neovascularization, and retinal detachment. FASEB J. 17(8):896-898; 2003.

193. Takahashi, K.; Yamanaka, S. Induction of pluripotent stem cells from mouse embryonic and adult fibroblast cultures by defined factors. Cell 126(4):663-676; 2006.

194. Takanaga, H.; Tsuchida-Straeten, N.; Nishide, K.; Watanabe, A.; Aburatani, H.; Kondo, T. Gli2 is a novel regulator of sox 2 expression in telencephalic neuroepithelial cells. Stem Cells 27(1):165-174; 2009.

195. Thompson, L. H.; Andersson, E.; Jensen, J. B.; Barraud, P.; Guillemot, F.; Parmar, M.; Björklund, A. Neurogenin2 identifies a transplantable dopamine neuron precursor in the developing ventral mesencephalon. Exp. Neurol. 198(1):183-198; 2006.

196. Toniatti, C.; Bujard, H.; Cortese, R.; Ciliberto, G. Gene therapy progress and prospects: Transcription regulatory systems. Gene Ther. 11(8):649-657; 2004.

197. Trounson, A. New perspectives in human stem cell therapeutic research. BMC Med. 7:29; 2009.

198. Trounson, A.; Thakar, R. G.; Lomax, G.; Gibbons, D. Clinical trials for stem cell therapies. BMC Med. 9:52; 2011.

199. Urlinger, S.; Baron, U.; Thellmann, M.; Hasan, M. T.; Bujard, H.; Hillen, W. Exploring the sequence space for tetracycline-dependent transcriptional activators: Novel mutations yield expanded range and sensitivity. Proc. Natl. Acad. Sci. USA 97(14):7963-7968; 2000.

200. Van Hoof, D.; D'Amour, K. A.; German, M. S. Derivation of insulin-producing cells from human embryonic stem cells. Stem Cell Res. 3(2-3):73-87; 2009.

201. Vierbuchen, T.; Ostermeier, A.; Pang, Z. P.; Kokubu, Y.; Südhof, T. C.; Wernig, M. Direct conversion of fibroblasts to functional neurons by defined factors. Nature 463(7284):1035-1041; 2010.

202. Vija,L.;Farge, D.; Gautier, J.F.; Vexiau,P.; Dumitrache,C.; Bourgarit, A.; Verrecchia, F.; Larghero, J. Mesenchymal stem cells: Stem cell therapy perspectives for type 1 diabetes. Diabetes Metab. 35(2):85-93; 2009.

203. Vitelli, F.; Morishima, M.; Taddei, I.; Lindsay, E. A.; Baldini, A. Tbxl mutation causes multiple cardiovascular defects and disrupts neural crest and cranial nerve migratory pathways. Hum. Mol. Genet. 11(8):915-922; 2002.

204. Wang, Y.; Cheng, X.; He, Q.; Zheng, Y.; Kim, D. H.; Whittemore, S. R.; Cao, Q. L. Astrocytes from the 
contused spinal cord inhibit oligodendrocyte differentiation of adult oligodendrocyte precursor cells by increasing the expression of bone morphogenetic proteins. J. Neurosci. 31(16):6053-6058; 2011.

205. Wang, Z.; Xu, G.; Wu, Y.; Liu, S.; Sun, B.; Dai, Q. Neuregulin-1 promotes cardiomyocyte differentiation of genetically engineered embryonic stem cell clones. BMB Rep. 41(10):699-704; 2008.

206. Weber, W.; Fussenegger, M. Pharmacologic transgene control systems for gene therapy. J. Gene Med. 8(5):535$556 ; 2006$

207. Wernig, M.; Lengner, C. J.; Hanna, J.; Lodato, M. A.; Steine, E.; Foreman, R.; Staerk, J.; Markoulaki, S.; Jaenisch, R. A drug-inducible transgenic system for direct reprogramming of multiple somatic cell types. Nat. Biotechnol. 26(8):916-924; 2008.

208. Wichterle, H.; Lieberam, I.; Porter, J. A.; Jessell, T. M. Directed differentiation of embryonic stem cells into motor neurons. Cell 110(3):385-397; 2002.

209. Williams, A. H.; Liu, N.; van Rooij, E.; Olson, E. N. MicroRNA control of muscle development and disease. Curr. Opin. Cell Biol. 21(3):461-469; 2009.

210. Winkler, C.; Fricker, R. A.; Gates, M. A.; Olsson, M.; Hammang, J. P.; Carpenter, M. K.; Björklund, A. Incorporation and glial differentiation of mouse EGFresponsive neural progenitor cells after transplantation into the embryonic rat brain. Mol. Cell. Neurosci. 11(3):99-116; 1998.

211. Wolf, D.; Goff, S. P. Embryonic stem cells use ZFP809 to silence retroviral DNAs. Nature 458(7242):1201$1204 ; 2009$.

212. Wollert, K. C.; Drexler, H. Cell therapy for the treatment of coronary heart disease: A critical appraisal. Nat. Rev. Cardiol. 7(4):204-215; 2010.

213. Wu, S. M.; Fujiwara, Y.; Cibulsky, S. M.; Clapham, D. E.; Lien, C. L.; Schultheiss, T. M.; Orkin, S. H. Developmental origin of a bipotential myocardial and smooth muscle cell precursor in the mammalian heart. Cell 127(6):1137$1150 ; 2006$

214. Wu, S. S.; Frucht, S. J. Treatment of Parkinson's disease: What's on the horizon? CNS Drugs 19(9):723$743 ; 2005$

215. Xie, H.; Ye, M.; Feng, R.; Graf, T. Stepwise reprogramming of B cells into macrophages. Cell 117(5):663676; 2004.

216. Xie, Q. P.; Huang, H.; Xu, B.; Dong, X.; Gao, S. L.; Zhang, B.; Wu, Y. L. Human bone marrow mesenchymal stem cells differentiate into insulin-producing cells upon microenvironmental manipulation in vitro. Differentiation 77(5):483-491; 2009.

217. Yandava, B. D.; Billinghurst, L. L.; Snyder, E. Y. "Global” cell replacement is feasible via neural stem cell transplantation: Evidence from the dysmyelinated shiverer mouse brain. Proc. Natl. Acad. Sci. USA 96(12):70297034; 1999.

218. Yechoor, V.; Liu, V.; Espiritu, C.; Paul, A.; Oka, K.; Kojima, H.; Chan, L. Neurogenin3 is sufficient for transdetermination of hepatic progenitor cells into neo-islets in vivo but not transdifferentiation of hepatocytes. Dev. Cell 16(3):358-373; 2009.

219. Yoon, S. Co-expressing $P d x 1$ and $N g n 3$ induces few $\beta$-like cells in the liver of mice. Biochem. Biophys. Res. Commun. 362(1):101-106; 2007.

220. Young, A.; Assey, K. S.; Sturkie, C. D.; West, F. D.; Machacek, D. W.; Stice, S. L. Glial cell line-derived neurotrophic factor enhances in vitro differentiation of mid-/ hindbrain neural progenitor cells to dopaminergic-like neurons. J. Neurosci. Res. 88(15):3222-3232; 2010.

221. Zahir, T.; Chen, Y. F.; MacDonald, J. F.; Leipzig, N.; Tator, C. H.; Shoichet, M. S. Neural stem/progenitor cells differentiate in vitro to neurons by the combined action of dibutyryl cAMP and interferon- $\gamma$. Stem Cells Dev. 18(10):1423-1432; 2009.

222. Zhou, B. Y.; Ye, Z.; Chen, G.; Gao, Z. P.; Zhang, Y. A.; Cheng, L. Inducible and reversible transgene expression in human stem cells after efficient and stable gene transfer. Stem Cells 25(3):779-789; 2007.

223. Zhou, H.; Wu, S.; Joo, J. Y.; Zhu, S.; Han, D. W.; Lin, T.; Trauger, S.; Bien, G.; Yao, S.; Zhu, Y.; Siuzdak, G.; Schöler, H. R.; Duan, L.; Ding, S. Generation of induced pluripotent stem cells using recombinant proteins. Cell Stem Cell 4(5):381-384; 2009.

224. Zhou, Q.; Brown, J.; Kanarek, A.; Rajagopal, J.; Melton, D. A. In vivo reprogramming of adult pancreatic exocrine cells to $\beta$-cells. Nature 455(7213):627-632; 2008.

225. Zhou, Q.; Choi, G.; Anderson, D. J. The bHLH transcription factor Olig2 promotes oligodendrocyte differentiation in collaboration with Nkx2.2. Neuron 31(5):791-807; 2001

226. Zhou, X.; Vink, M.; Klaver, B.; Berkhout, B.; Das, A. T. Optimization of the Tet-On system for regulated gene expression through viral evolution. Gene Ther. 13(19):1382-1390; 2006.

227. Zhu, S.; Wurdak, H.; Wang, J.; Lyssiotis, C. A.; Peters, E. C.; Cho, C. Y.; Wu, X.; Schultz, P. G. A small molecule primes embryonic stem cells for differentiation. Cell Stem Cell 4(5):416-426; 2009. 